\title{
Observations from the 26th November 2019 Albania earthquake: the earthquake engineering field investigation team (EEFIT) mission
}

\author{
Fabio Freddi ${ }^{1}$. Viviana Novelli ${ }^{2} \cdot$ Roberto Gentile $^{1,3} \cdot$ Enes Veliu $^{4} \cdot$ Stoyan Andreev $^{5}$. \\ Anton Andonov ${ }^{5} \cdot$ Federica Greco $^{6} \cdot$ Emiljano Zhuleku $^{7}$
}

Received: 8 August 2020 / Accepted: 10 February 2021 / Published online: 4 March 2021

(C) The Author(s) 2021

\begin{abstract}
On the 26th of November 2019, an earthquake of moment magnitude 6.4 struck the northwest region of Albania as the result of thrust faulting near the convergent boundary of the Africa and Eurasia plates causing widespread damage to buildings in the city of Durrës and the surrounding areas. Based on the official data from the national authorities, the earthquake caused 51 casualties and 985 million-euro losses, corresponding to $7.5 \%$ of the 2018 gross domestic product. This paper summarises field observations made by the Earthquake Engineering Field Investigation Team (EEFIT) after the event. The paper presents an overview of the seismological aspects of the earthquake together with a brief overview of the damage, official loss statistics and the estimated macro- and socio-economic consequences of the event. In addition, it provides a summary of the observed damage to both recent and historical buildings as well as the description of several case studies to illustrate the characteristic damage patterns observed in the main structural typologies of the Albanian building stock. These observations try to identify possible links between the observed damage patterns and the deficiencies in construction practice and use of inappropriate retrofit techniques for historical assets. As many severe damages were observed on modern buildings, this also allows the identification of some gaps and possible areas of development of the current seismic design code. In the end, the lessons learned from the field survey are resumed.
\end{abstract}

Keywords Albania earthquake $\cdot$ Field survey $\cdot$ Post-earthquake reconnaissance $\cdot$ Buildings damage assessment

\section{Introduction}

On Saturday 21st September 2019 at 15:15 CET, an earthquake of moment magnitude $\left(\mathrm{M}_{\mathrm{w}}\right) 5.6$ and shallow focal depth ( $\left.10 \mathrm{~km}\right)$ (Bilgin and Hysenlliu 2020; USGS 2020) hit the northwest region of Albania. The epicentre of the earthquake was estimated to be on

Fabio Freddi

f.freddi@ucl.ac.uk

Extended author information available on the last page of the article 


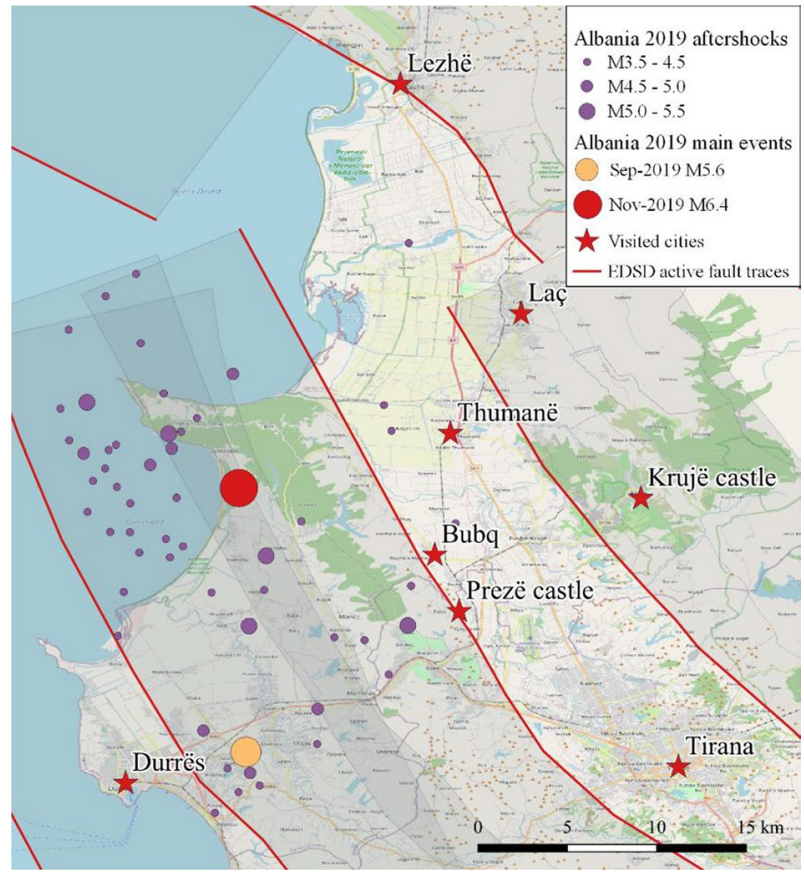

Fig. 1 Albanian earthquake sequence of 2019 and visited locations during the EEFIT mission

the outskirts of Durrës. Despite the proximity to the city, the event had relatively small consequences with no fatalities, i.e., 110 injured people and 120 damaged buildings without structural failures. This was the first event of the seismic sequence and, on the 26th November, at 03:54 CET, central and north-west Albania was struck by the mainshock of the sequence with $\mathrm{M}_{\mathrm{w}} 6.4$ and shallow focal depth ( $20 \mathrm{~km}$ ) (USGS 2020). The epicentre was $16 \mathrm{kms}$ west-southwest of the town of Mamurras in Kurbin municipality. The maximum felt intensity near the epicentre was VIII (Severe) on the Modified Mercalli Intensity scale (USGS 2020). The earthquake was felt strongly in Albania's capital Tirana where the significant duration (bracketed between the 5\% and 95\% of Arias intensity) of the strong motion was $24 \mathrm{~s}$. The earthquake was also felt in places as far away as Taranto (Italy) and Belgrade (Serbia). A total of 51 people were killed in the earthquake, with about 3,000 injured. The first estimates revealed that the total effect of the disaster in the 11 municipalities amounts to 985 million euro, including direct and indirect losses (Republic of Albania Council of Ministers 2020). This was the strongest earthquake to hit Albania in more than 40 years (after the 1979 Montenegro, Shkoder earthquake with $M_{w} 6.9$ ), its deadliest earthquake in 99 years and the world's deadliest earthquake of 2019 (Bilgin and Hysenlliu 2020). After three aftershocks with $M_{w} 5.1$ to 5.4 on the same day, the seismic activity continued for few months with regular $\mathrm{M}_{\mathrm{w}} \sim 4$ earthquakes until at least the beginning of January 2020. The estimated epicentres and magnitudes of the felt earthquakes $\left(M_{w}>3.5\right)$ in the sequence based on ANSS Comprehensive earthquake catalogue (USGS 2020) are shown in Fig. 1.

The earthquake affected at least 11 of the country's 61 municipalities, including the two most populous, urbanised, and developed cities Tirana and Durrës. The worst affected municipalities were: Durrës, Tirana, Krujë, Shijak, Kamëz, Kavajë, Kurbin and Lezhë. The 
earthquake resulted in the collapse of several buildings which caused casualties and widespread damage to both historical and newly designed buildings. The broad range of affected buildings is representative of construction types in many European countries, drawing particular interest to this earthquake by the European earthquake engineering community.

The Earthquake Engineering Field Investigation Team (EEFIT) (www.istructe.org/getinvolved/supported-organisations/eefit) decided to organise a reconnaissance mission to the Albanian region following the earthquake. The mission was held from the 13th to the 18th of December 2019 and first visited the areas of Bubq, Laç and Lezhë as locations of interest. In addition, visits were made to the city of Durrës, with particular attention to the Durrës Beach area, and the village of Thumanë. Both were extensively covered in the media since almost all casualties were from these two locations and have been extensively investigated. To understand the earthquake impact on the Albanian heritage, Durrës, Krujë and Prezë castles were also visited as extensive structural damage was highlighted at these three historic sites. The locations of the visited areas are illustrated in Fig. 1.

The present paper illustrates some of the key findings of the EEFIT mission. The paper starts with a description of the event with reference to the region's historical seismicity and tectonics. It then discusses the evolution of the seismic design codes in Albania, the Albanian building stock, the estimated losses, and the outcomes of the rapid visual survey with the aim of providing an overview of the situation at large scale after the earthquake, hence allowing the identification of relevant case studies. Finally, it presents field observations of a few relevant case studies that have been investigated in detail and for which damage patterns are identified and discussed in relation to the geometric and structural features observed for the damaged constructions. The final section provides final remarks and lessons learned from the mission. Further images from the field mission can be accessed from the EEFIT website.

\section{The 26th November 2019 earthquake}

The 26th November 2019 earthquake was recorded at seven seismic monitoring stations of the Albanian Seismological Network (www.geo.edu.al/newwe $\mathrm{b} / ? \mathrm{fq}=\mathrm{bota} \& \mathrm{gj}=\mathrm{gj} 2 \& \mathrm{kid}=20$ ), located at epicentral distances from 15 to $130 \mathrm{~km}$ (Duni and Theodoulidis 2019). Figure 2a, b show the North-South (N-S) and East-West (E-W) components of the ground motions recorded by two different accelerometric stations: one in Tirana, Albania's largest city by area and population (station TIR1); one in Durrës, one of the most affected areas by the November's earthquake (station DURR). The accelerometric stations in Tirana and Durrës are located at $33.7 \mathrm{~km}$ and $15.6 \mathrm{~km}$ from the epicentre, respectively. Both stations are located on ground type $\mathrm{C}$ sites as per Eurocode 8 with average shear wave velocities in the upper $30 \mathrm{~m} \mathrm{~V}_{\mathrm{s} 30}=202 \mathrm{~m} / \mathrm{s}$ at DURR and $312 \mathrm{~m} / \mathrm{s}$ at TIR1. The PGA and moment magnitude values for the four strongest events of 2019 recorded between September and November are shown in Table 1.

The horizontal Peak Ground Acceleration (PGA) recorded in Tirana was approximately $0.12 \mathrm{~g}$, whereas in Durres (closer to the epicentre) this value was about $0.20 \mathrm{~g}$. However, it is worth mentioning that the accelerometric station in Durrës only recorded the event for the first $15 \mathrm{~s}$ due to a power outage caused by the earthquake, hence the $0.20 \mathrm{~g}$ value represents a lower bound of the actual PGA felt at the site. In order to understand the impact of the earthquake, Fig. 2c, d show the response spectra from the recorded ground motions versus the elastic response spectra defined according to the Albanian code (KTP-N.2-89 

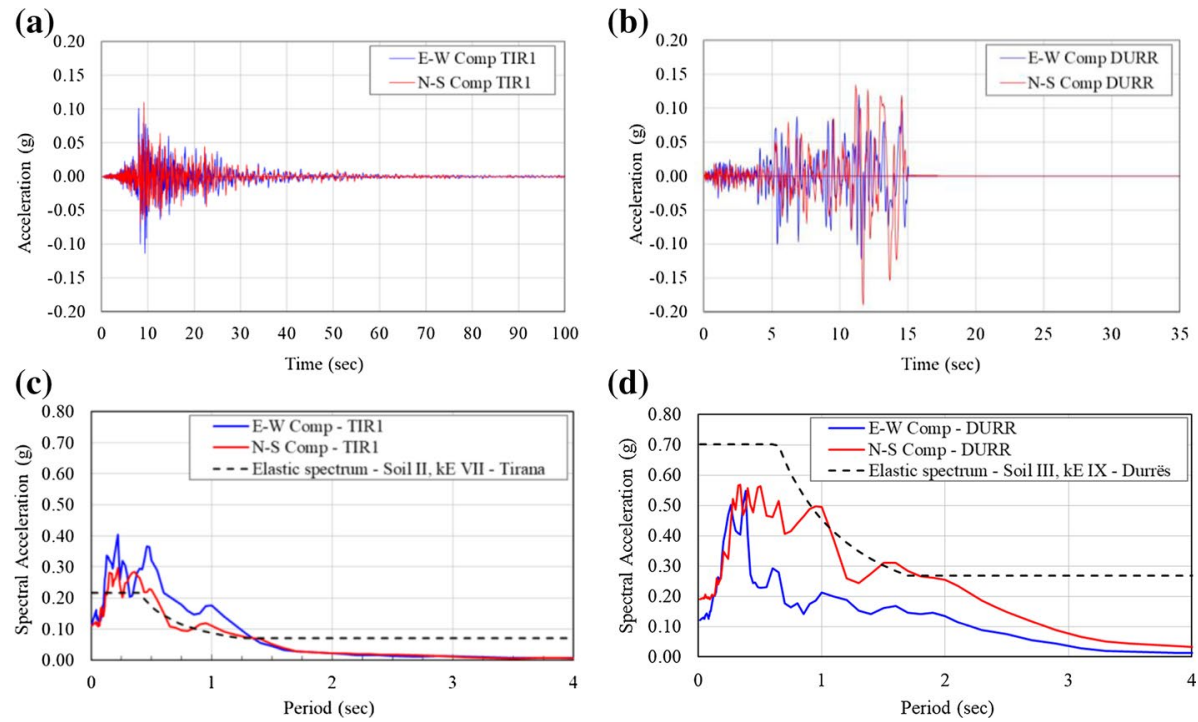

Fig. 2 Ground motions recorded in a Tirana (TIR1 Station) and b Durrës (DURR station) during the 26th November earthquake (www.geo.edu.al/newweb/?fq=bota\&gj=gj2\&kid=20). KTP-N.2-89 elastic spectra vs response spectra in c Tirana (TIR1 Station) and d Durrës (DURR station)

Table 1 Measured PGA values at DURR and TIR1 stations in the four strongest events in 2019

\begin{tabular}{lccl}
\hline Date & $\mathrm{M}_{\mathrm{w}}$ & PGA—DURR (g) & PGA—TIR1 (g) \\
\hline 21st September & 5.6 & 0.12 & 0.18 \\
21st September & 5.1 & 0.10 & 0.03 \\
26th November & 6.4 & $\geq 0.20$ & 0.12 \\
26th November & 5.4 & 0.04 & 0.02 \\
\hline
\end{tabular}

1989) for soils II and III, corresponding to the soil types at the locations of the accelerometric stations in Tirana and Durrës, respectively.

In Tirana, the recorded spectral accelerations, shown in Fig. 2c, are between 1.4 and 2.0 times higher than the code provision at spectral periods 0.2 to $1.0 \mathrm{~s}$, where most buildings in the affected areas are expected to have their fundamental period. Conversely, for the city Durrës, the response elastic design spectrum, shown in Fig. 2d, is higher that the response spectra of the recorded ground motions in both directions. The only exception is for the natural period range of 1 to $2 \mathrm{~s}$, where the spectrum of the recorded ground motion for the $\mathrm{N}-\mathrm{S}$ component is comparable to the code-based elastic response spectrum. However, as already mentioned, this comparison could not be representative of the reality due to the limited data for the ground motion recorded at the Durrës station.

\subsection{Tectonics and historical records}

The tectonic setting of the Mediterranean Sea, in the convergent boundary region between the African and Eurasian plates, is complex, and involve the motions of numerous microplates and regional-scale structures, such as the Adria plate (Robertson and 
Shallo 2000). In fact, the convergence of the Adria and Moesia plates across the Southern Dinarides is the direct cause of the seismic activity in Albania (Grünthal and Wahlström 2012). In the context of the November earthquake, reverse faulting in Albania on the eastern shores of the Adriatic Sea is consistent with the closing of that sea and shortening across the mountain belts stretching from Croatia to Greece. Due to the complex tectonic setting of the Southern Dinarides and continuous convergence along the plate boundaries, a large number of geological faults in Albania are currently active and can produce earthquakes with $\mathrm{M}_{\mathrm{w}}$ above 6.5 (Métois et al. 2019). A large number of moderate-to-strong earthquakes $\left(\mathrm{M}_{\mathrm{w}}>4.5\right)$ have been observed in the Albanian territory since historical times, as seen from the European-Mediterranean Earthquake Catalogue (EMEC) (Grünthal and Wahlström 2012). A complete list of past strong earthquakes is provided by Bilgin and Hysenlliu 2020.

\subsection{Geotechnical conditions and observed effect of soil}

The November earthquake affected areas with different soil conditions-from very soft and potentially liquefiable recent deposits in the coastal regions, through deep alluvium medium-stiffness deposits in the plane area around Tirana, to rock outcrops in the mountainous areas. The varying soil stiffness and stratification determine very different local site response across the affected area-from no amplification to high amplification of the ground motions with respect to the underlying bedrock. According to Stein and Sevilgen (2020), most of central Albania is characterised by at least moderate ground motion amplification while areas such as Durrës, Lezhë, and Thumanë are characterised by high amplification effects as shown in Fig. 3. The predicted high amplifications in these cities are in agreement with the severity of damage observed in these areas, being the most affected ones by the earthquake. Except for soil subsidence and near surface liquefaction in the Durrës Beach area, no widespread manifestations of the potential geohazards were observed and no damage related to them was reported. Due to the scarcity of reported damage from earthquake-induced geohazards, i.e., very few locations affected by liquefaction, the EEFIT mission did not investigate this aspect.

Fig. 3 Estimated ground motion amplification based on inferred $\mathrm{V}_{\mathrm{s} 30}$ values (Adapted from to Stein and Sevilgen 2020)

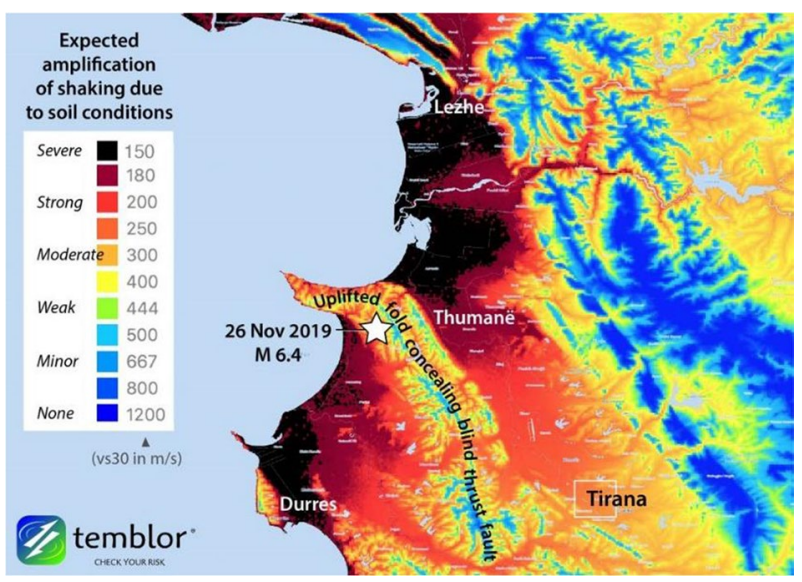




\section{Seismic design codes in Albania}

Albania has a long history of code-regulated seismic design, as shown in Fig. 4. The first seismic regulations, accompanied by the first seismic zonation of Albania, were adopted in 1952. The revision of 1963 increased the seismic design requirements, while the revision in 1978 with the KTP 2-78 brought no significant improvements (UNDP Albania 2003). In 1989 the new seismic design code, KTP-N.2-89, was released, and it is currently the official seismic design code in Albania.

The KTP-N.2-89 covers a broad range of structural configurations and, for each of them, provides design provisions. Consistently with modern seismic provisions worldwide, the KTP-N.2-89 is based on the design concept of providing the structure with adequate ductility, allowing the dissipation of the seismic input energy through nonlinear cyclic deformations without compromising its integrity. It includes principles common to many modern seismic design codes for building structures, such as the regularity in plan and elevation, including considerations on the mass and stiffness distribution, symmetry, simplicity, etc. The seismic hazard is defined through macro-seismic intensity areas, defined according to the MSK-64 scale (Medvedev et al. 1965) and dividing the country into three large seismic zones with intensity VI, VII, VIII. It also denotes some areas, located in proximity of the epicentres of large seismic events, where the seismic intensity VIII is increased by one intensity level to IX at sites with poor soil conditions. Three soil types are defined (i.e., I, II and III) and differentiated for each of the identified seismic zones. In addition, the code provides guidelines for the definition of the seismic design actions considering the influence of the torsional effects, the load combinations in the case of the seismic design situation, and the partial factors in the load combinations. The analysis methods include the modal response spectrum analysis or time history analysis for more complex structures.

The horizontal design acceleration response spectrum is defined according to the following equation:

$$
S_{a}(T)=k_{E} k_{r} \psi \beta g
$$

where $k_{E}$ is the seismicity coefficient that depends on the seismic intensity and soil category, $k_{r}$ is the importance coefficient ( 1 for ordinary buildings), $\psi$ is the structural response coefficient under the earthquake action (used to derive the design spectrum from the elastic one similarly to the behaviour factor of the Eurocode 8 ), $\beta$ is the dynamic coefficient that depends on the building natural periods and the soil category, $g$ is the gravitational acceleration. The structural coefficient, $\psi$, is given for several construction materials and structural systems, e.g., the coefficient is 0.25 for $\mathrm{RC}$ bare frames, 0.2 for steel moment-resisting frames, 0.33 for systems composed of the combination of $\mathrm{RC}$ frames with shear walls, etc.

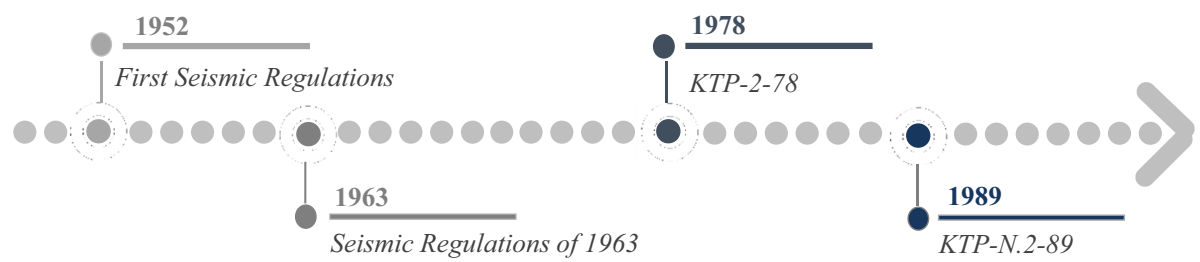

Fig. 4 Timeline of evolution of Albanian seismic design codes 
For unreinforced masonry (URM) structures, the material mechanical properties shall comply with the code minimum requirements. The masonry walls are classified into three seismic strength categories based on the mortar strength and masonry unit properties. There are limitations on the heights of stories as a function of the thickness of the wall and wall category, and limitations on the maximum distances between transversal walls. Limitations on the dimensions of openings, distances between consecutive openings, and other geometrical parameters are imposed in the code. In addition, the code requires masonry structures to be provided with reinforced concrete (RC) tie beams, and these beams to comply with detailing rules for stirrups and longitudinal rebars diameters, spacing, etc. The code also imposes detailing rules for confined masonry (CM) structures.

For RC structures, the code recognizes several lateral resisting systems, including moment-resisting frames, frames interacting with masonry infills, dual systems, or combinations of the previously mentioned systems. Moreover, for cast-in-situ RC members, such as beams, columns, and walls, it provides detailing rules to achieve local ductility. For frame structures in general, it requires plastic hinges to be limited to the beams, yet there is no specific recommendation to ensure that this requirement is satisfied.

It is worth noticing that the above conditions focus on protecting the structures from collapse while no detailed recommendations are provided regarding damage limitations. In fact, no inter-storey drifts limits are provided by the code to protect the infills by the in-plane loads, even though the code requires that infills maintain their integrity during seismic events. It is also stated that the infills shall be checked against out-of-plane failure. In this regard, there are guidelines provided on how to determine the seismic demand for non-structural components.

Considering the code as a whole, it can be stated that the KTP-N.2-89 shares common principles with modern seismic design codes such as Eurocode 8 (European Committee for Standardisation (CEN) 2005), but it lacks several detailing recommendations. For example, the KTP-N.2-89 code requires columns to be stronger with respect to the adjacent beams but does not provide a quantitative formulation to perform this hierarchy check. In order to overcome these issues, in the more recent years, the community of structural engineers often uses good practices from Eurocode 8 as integration to the KTP-N.2-89 in their everyday practice.

\section{Albanian building stock and estimated impact}

\subsection{Description of the building stock}

According to the housing 2001 census (Albanian Institute of Statistics (INSTAT) 2001), the Albanian building stock is mainly composed of four typologies i.e., prefabricated, bricks and stones, wood, and other construction materials. Although this is not the most updated one, this is the last census providing a building classification based on construction materials. Conversely, when referring to the most recent census of 2011 (Albanian Institute of Statistics (INSTAT) 2011), information related to the construction materials is not included, and buildings are classified according to their (low- to high-) rise and year of constructions.

Table 2 provides the overview of the Albanian building stock according to the available data in the 2001 census. According to this, the 'bricks and stones' category represents the vast majority of the building stock. However, it is noteworthy that, while the other categories 
Table 2 Classification of the Albanian building stock (Albanian Institute of Statistics (INSTAT) 2001)

\begin{tabular}{lclccc}
\hline Construction material & Pre-1945 & $1945-1960$ & $1961-1980$ & $1981-1990$ & $1991-1995$ \\
\hline Prefabricated concrete & 0 & 0 & 4601 & 5993 & 4575 \\
Bricks and stones (include & 37,416 & 63,870 & 141,174 & 102,198 & 43,324 \\
$\quad$ masonry and RC structures) & & & & & \\
Wood & 462 & - & 1821 & 1273 & 743 \\
Other & 2560 & 3393 & 7105 & 6263 & 4238 \\
Total & 40,438 & 68,468 & 154,701 & 115,727 & 52,880 \\
\hline
\end{tabular}

include a single and specific construction material, the 'bricks and stones' includes brick, stone masonry, but also RC structures.

According to the 2011 census (Albanian Institute of Statistics (INSTAT) 2011), the single-storey buildings account for $85 \%$ of the total housing building stock. By assuming that a single-storey building accommodates a single dwelling, this category accounts for $50 \%$ of the 1,012,400 dwellings reported in the latest census (approximately accommodating $50 \%$ of the population). These single-storey buildings include URM, CM structures made of stone, or clay or silicate bricks and RC frames with masonry infills made of lightweight clay or concrete bricks. The roof for these buildings is typically made of wooden trusses and rafters with clay tiles or flat RC slab. Rarely inclined RC slabs covered with clay tiles are adopted. Similar structural systems are conventionally used for two-storey buildings.

Although the total number of multi-storey residential buildings in Albania is significantly lower with respect to the single-storey houses, they accommodate the remaining 50\% of dwellings as commented above. Moreover, as shown in Sect. 6, the multi-storey housing buildings have been significantly affected by the November earthquake, given the higher damage observed during the field investigation. Figure 5 depicts typical multi-storey housing buildings in Albania. The most common ones are URM and CM structures with clay- or calcium silicate-bricks (Fig. 5a, b) and RC structures with masonry infills (Fig. 5c). In addition, prefabricated large-panel buildings (Fig. 5d), falling in the 'prefabricated' category of the 2001 census, are also included, as they constitute a representative typology for the Albanian building stock. The roofs of the multi-storey buildings are prevalently made of flat RC slabs. Moreover, it is worth mentioning that all the buildings taller than 6-storeys are RC frames.

Table 2 also provides information regarding the year of construction as an important parameter to identify the design code adopted for the single building class. Although the available data may be outdated, they still highlight that a large percentage of the Albanian buildings were constructed before 1990 and thus before the introduction of the 1989 seismic code as described in Sect. 3. After 1990, a significant growth in the number of buildings is observed. However, between 1990 and 2000, owing to the poor law enforcement and a lack of compliance with the design standards, numerous buildings were likely constructed without permission, and nor proper engineering assurance. Therefore, it is foreseeable that buildings built over this timeframe are likely to have deficiencies affecting their seismic performance.

\subsection{Economic and social impact of the earthquake}

The high seismic vulnerability described in Sect. 4.1 led to considerable economic losses as consequence of the November earthquake. Immediately after the event, a rapid post-disaster damage assessment consistent with the GRADE (Global RApid 

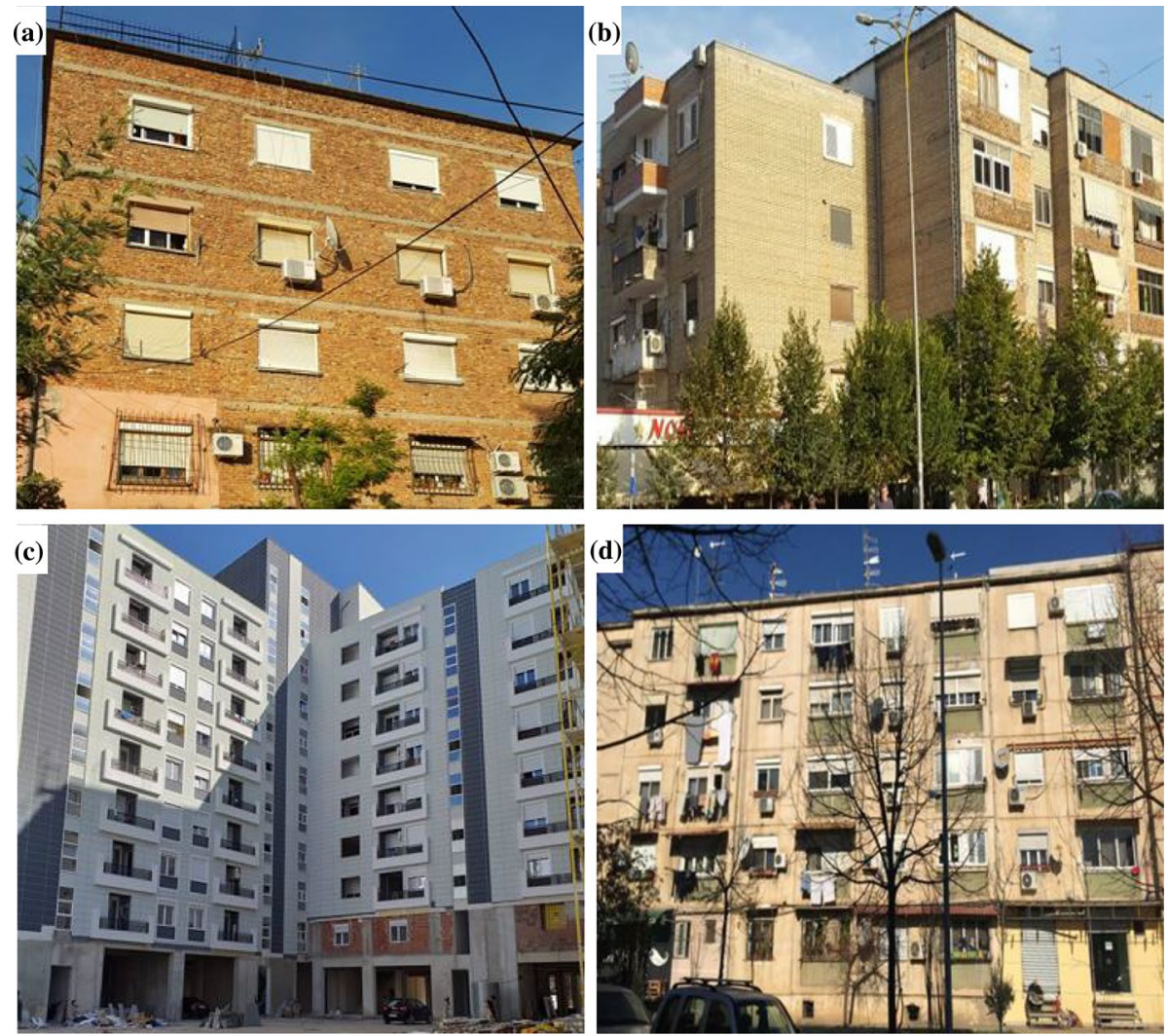

Fig. 5 Representative typologies of the multi-storey Albanian building stock: a unreinforced masonry building (URM) in clay bricks; b confined masonry (CM) building in silicate bricks; $\mathbf{c}$ new reinforced concrete (RC) building (under construction); d prefabricated large-panel building

post-disaster Damage Estimation) methodology, was undertaken by the World Bank (The World Bank GPURL D-RAS Team 2019). The objective was to estimate the economic impact of the earthquake, including its spatial distribution, to support recovery and reconstruction. Subsequently, in December 2019 and January 2020, this assessment was further developed in the form of a Post-Disaster Needs Assessment (PDNA) that was realised through collaborative efforts of the government of Albania and its international partners: the European Union, the United Nations agencies, and the World Bank (Republic of Albania Council of Ministers 2020).

The PDNA report reveals that the estimated total effect of the disaster in 11 municipalities amounts to 985 million euro, of which 844 million euro represent the value of destroyed physical assets and 141 million euro refer to indirect losses. As shown in Fig. 6a, most of the direct losses are recorded in the housing sector $(78.5 \%)$, followed by the productive $(8.4 \%)$ and the education $(7.5 \%)$ sectors. Regarding the indirect losses, the productive sector accounts for the highest share of $56.4 \%$, followed by $24.1 \%$ for housing and $9.4 \%$ for the strategic assets (e.g., civil protection, healthcare infrastructures, social protection). Therefore, $76.5 \%$ of the overall losses refers to the private sector (mainly housing and productive), while $23.5 \%$ refers to the remaining publicly owned sectors. 
(a)

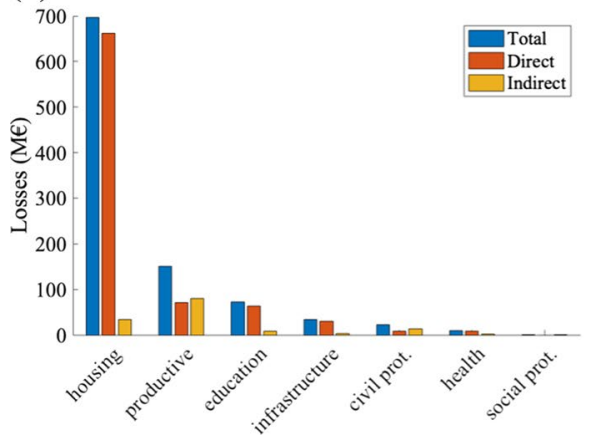

(b)

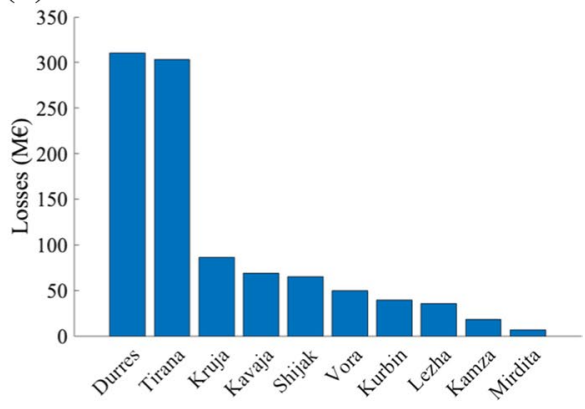

Fig. 6 Economic losses according to the PDNA report (Republic of Albania Council of Ministers 2020): a by sector; $\mathbf{b}$ by municipality

The geographic distribution of losses is illustrated in Fig. 6b. The municipality of Durrës was overwhelmingly the most affected one with 304 million euro of losses $(32.4 \%$ of the total), followed closely by Tirana with 284 million euro (30\%), and Krujë with 84 million euro (9\%). It is worth mentioning, however, that the losses in the Tirana municipality are particularly high due to the large extension of the municipality itself rather instead of high concentrated losses in the city (where only minor damage was observed). In fact, such municipality is considerably larger than the others reported in Fig. 6 b.

The PDNA report shows that the earthquake has caused effects equivalent to $6.4 \%$ and $1.1 \%$ of the 2018 gross domestic product (GDP) respectively in direct and indirect losses. The GDP growth impact projections is based on the estimated production losses at sector level, accounting for smaller economic gains of other sectors. Before the earthquake, the Albanian economy was projected to grow by an estimated 3.5\% in 2020. Such estimate is now reduced to $3.2 \%$ (approximately 98 million euro decrease). The PDNA report shows also the results of the Survey of Household Damages due to Earthquake (SHDE, United Nations Albania 2020) to evaluate the impact of the earthquake on poverty and human development. The comparison of the at-risk-of-poverty rates before and after the earthquake indicates that the number of estimated at-risk-of-poverty people has increased across municipalities. The highest value of relative poverty is recorded in Kurbin (52.9\%) followed by Kamza (39.2\%). The lowest at-risk-of-poverty rate is recorded in Durrës (8.7\%), followed by Shijak (15.4\%).

\section{Rapid visual survey}

EEFIT missions over time have demonstrated the singularity of each post-disaster scenario and therefore the need of an ad hoc planning of each mission. Therefore, the rapid visual survey of the structures affected by the November 2019 Albanian earthquake was undertaken collecting the information provided in Table 3 . The collected information was shaped around the specific needs of this mission, especially considering that a fast, exterior-only survey was generally targeted. In depth information, not included in this table, was collected for few selected case studies (see Sect. 6). 
Table 3 List of collected information

\begin{tabular}{ll}
\hline Building identifier & Basement (yes/no) \\
\hline Person recording & Year of construction \\
Time of the inspection & Structural system \\
Date of the inspection & $\begin{array}{l}\text { Constructional material of the } \\
\text { masonry bearing walls or infill } \\
\text { panels }\end{array}$ \\
Location (city, address) & Extension (yes/no) \\
Latitude & Date of extension \\
Longitude & Roof typology \\
Occupancy type & Floor typology \\
Access (interior, exterior) & EMS 98 damage state \\
Current occupation state & Failure mechanism \\
Number of floors & Comments \\
\hline
\end{tabular}

Therefore, the attention was focused on identifying the building location, broad information about geometry, building typology (including the structural system, the roof and floor typologies), and general comments about the failure mechanism (if any). With particular reference to the qualitative damage assessment, the European macro-seismic scale (EMS-98, Grünthal 1998) was adopted. This involves five damage states-from DS1, light damage, to DS5, total collapse in addition to the no damage state (DS0)defined for buildings with mixed structural systems, RC frames, prefabricated largepanel, URM and CM walls, as well as historical assets.

During this mission, the information was stored in a spreadsheet and uploaded on a server at the end of each day. Moreover, the team decided to experiment the use of two damage assessment apps, under development at the time of the mission, to provide feedback to the developers. The damage assessment apps were respectively provided by EEFIT (https://research.ncl.ac.uk/learningfromearthquakes/) and Bristol University (www.safernepal.net).

During the four days of field mission, about 70 structures were inspected. Of these, $26 \%$ were accessed also on the inside, whereas the rest of the buildings were inspected from the outside only. Apart from the largely-affected areas of Durrës and Durrës Beach, the team visited other affected areas such as Bubq, Prezë, Laç, Lezhë, Krujë, and Thumanë as shown in Fig. 1. The number of buildings visited in each of these areas is reported in Fig. 7a. The team visited Tirana, and no damaged buildings were observed confirming that the high economic losses registered for the Tirana municipality do not refer to the city itself but to the surroundings areas (Sect. 4.2).

Multiple building typologies were identified (Fig. 7b), the majority of these were RC frames (without any core wall or with a small core) and URM, which approximately represent respectively $65 \%$ and $30 \%$ of the inspected building portfolio. Other identified building typologies include prefabricated large-panel and CM buildings.

$70 \%$ of the inspected buildings has a residential use while the remaining are public buildings including schools, hospital, and fire brigades. The EEFIT team also visited selected cultural heritage sites including several towers, and religious buildings, and fortification walls. One bridge was also included in the mission, representing the only assessed infrastructure. 
(a)

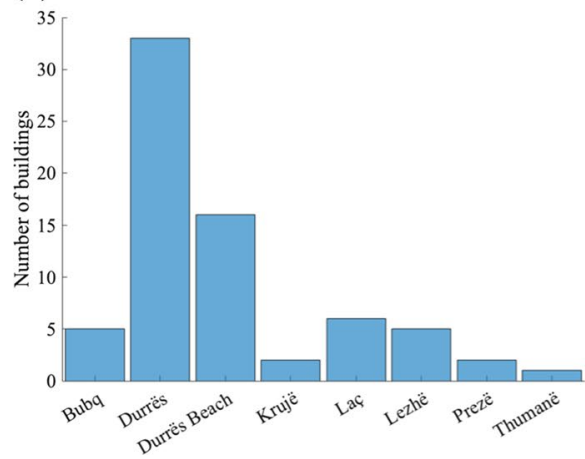

(b)

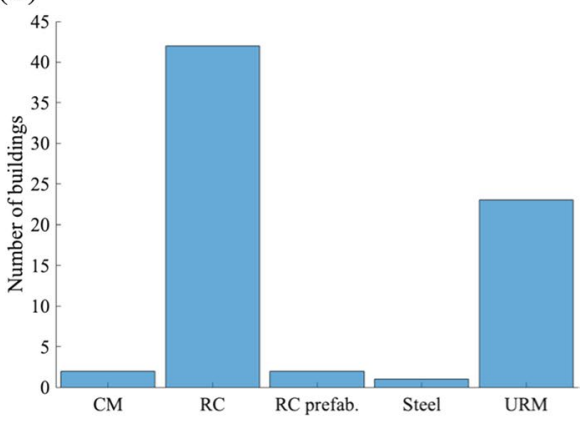

Fig. 7 General information collected in the rapid visual survey: a location; b structural system. CM: confined masonry; RC: reinforced concrete; prefab: prefabricated; URM: unreinforced masonry

The qualitative damage assessment results are summarised in Fig. 8. Consistently with the mission objectives, the limited number of surveyed buildings provides only qualitative insights on the location, number of storeys, year of construction and the general damage severity (defined according to the EMS-98 scale), disaggregated by structural typology/ material.

First, Fig. 8a shows that the majority of the investigated buildings in Durres are made of RC, while URM ones are encountered almost uniformly in all the visited areas. Within the investigated portfolio, the URM ones are characterised by a maximum of five storeys (Fig. 8b). As expected, most of these buildings were built before the 1990 (Fig. 8c). About 10 of the inspected URM buildings were assigned to DS4 due to the serious structural failure observed on the masonry walls and slabs. Only a few CM buildings were surveyed and only one of those has shown a widespread damage condition, and it was assigned to DS4 (Fig. 8d).

The RC buildings vary between 2- and 12-storeys, with 10 -storeys ones being the most frequent among those inspected. Approximately 30 of the inspected RC buildings were built after the 2000s, while less than 10 were built between the 1980s and 1990s (Fig. 8c). The vast majority of the RC buildings was assigned to DS3 (Fig. 8d), mainly due to the cracks in the infill walls, often with expulsion of individual infill panels. It is worth mentioning, however, that none-to-very little structural damage to RC members was observed. Many 5-storey prefabricated large-panel buildings were identified in Durrës and the other districts, some of which have been visited during the field mission. The year of construction of these structures is likely to be around the 1980s (Fig. 8c). All the prefabricated large-panel buildings (RC prefabricated in the figures) have shown a negligible damage condition consistent with DS1 (Fig. 8d). Only minor cracks were found in the joints between the panels, with no observed damage in the dowel connections.

\section{Investigated case study buildings}

This Section presents field observations of a few relevant case studies classified according to the representative typologies of the Albanian building stock discussed in Sect. 4, as well as historic buildings. Their geometric and structural features are described in detail 
(a)

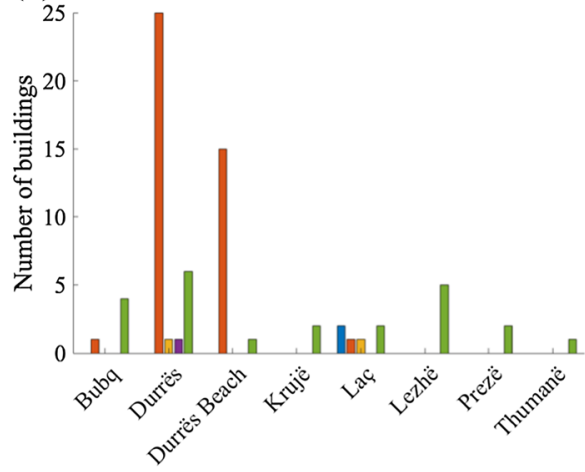

(c)

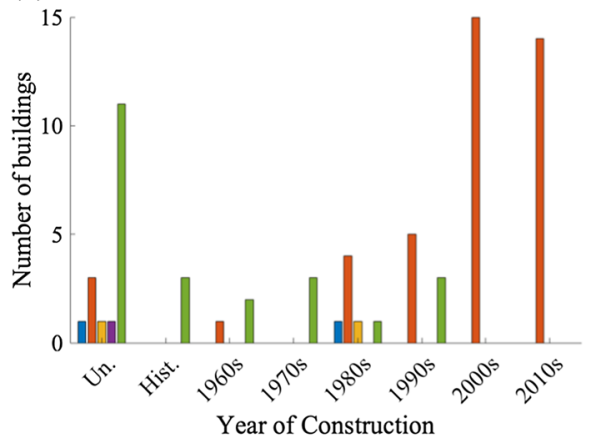

(b)

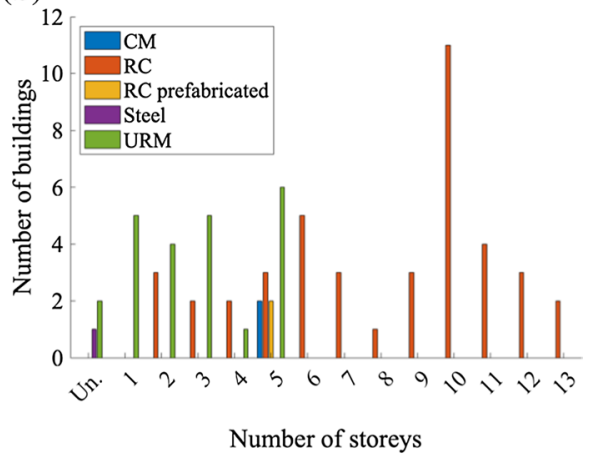

(d)

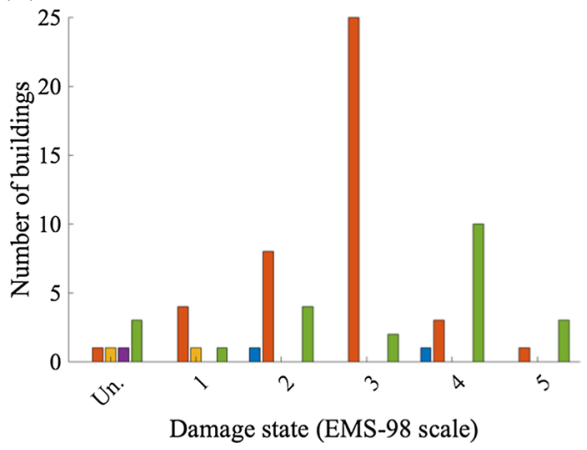

Fig. 8 Rapid visual survey summary: a location; $\mathbf{b}$ number of stories; $\mathbf{c}$ year of construction; $\mathbf{d}$ damage state (EMS-98 scale). Un: unknown; Hist: historical; CM: confined masonry; RC: reinforced concrete; URM: unreinforced masonry

to provide an overview of the construction practice. Damage patterns and severity are discussed and critically interpreted to highlight the strength and deficiencies of the structural and non-structural elements of the inspected constructions and identify the causes associated to the good and poor seismic performance observed in field. The following considerations and discussion on the damage scenarios are based on the visual inspection of the case studies while a detailed analysis (i.e., the use of advanced numerical models) is beyond the scope of the present paper.

\subsection{Single-family rural houses}

Single-family rural houses represent a widespread typology in Albania. During the mission this typology have been widely inspected considering several case studies in the village of Bubq in Krujë municipality. Some of these houses, according to information gained from local engineers, were already damaged by the earthquake in September 2019, and then collapsed in the seismic event on the 26th November. No casualties were reported in this area, although many of these structures showed a poor seismic response mainly caused by an inadequate seismic design and unauthorised interventions carried out by local artisans with little input from engineers. 
The house in Fig. 9a, located in Bubq, has the typical configuration of the single-family rural houses in this area. It is a 2-storey house, classified as URM building. The 1st storey was built in 1992 by the owner by using bearing walls made of hollow concrete blocks and cement mortar (Fig. 9b) and a solid RC slab. In 1997, a portico porch made of RC columns was added, and a 2 nd storey was built supported by the 1 st storey and the columns of the portico porch. The bearing walls of the 2 nd storey are also made of concrete blocks while the floor is made with a hollow core prefabricated concrete slab (Fig. 9c) supporting a timber truss for the roof tiles (Fig. 9a). The house, which was already damaged by the earthquake in September, completely collapsed during the following earthquake in November. The observed failure is caused by the collapse of the portico porch, which failed for soft storey due to the uneven mass distribution between the 1 st and 2 nd level. The rear view of the house in Fig. 9c shows a severe crack in the pier at the 1st level, due to a torsional effect in the building caused by the collapse of the portico porch. Detailing of the RC columns, supporting part of the 2nd storey, are reported in Fig. 9e, where it is possible to see the joint failure of the top end of the column. Figure 9f shows a close-up of a different joint highlighting the lack of adequate reinforcements with smooth and corroded rebars.

Similar failures and cracks were also observed in other single-family houses of the same typology with floor plans which differ in sizes. Local engineers confirmed that the 1st and the 2nd levels of these inspected houses were also built at different time, using different materials and structural floors for the 1st and 2nd level. Figure 10 shows the failure of a single-family house with a geometry plan smaller than the ones in Fig. 9. The observed
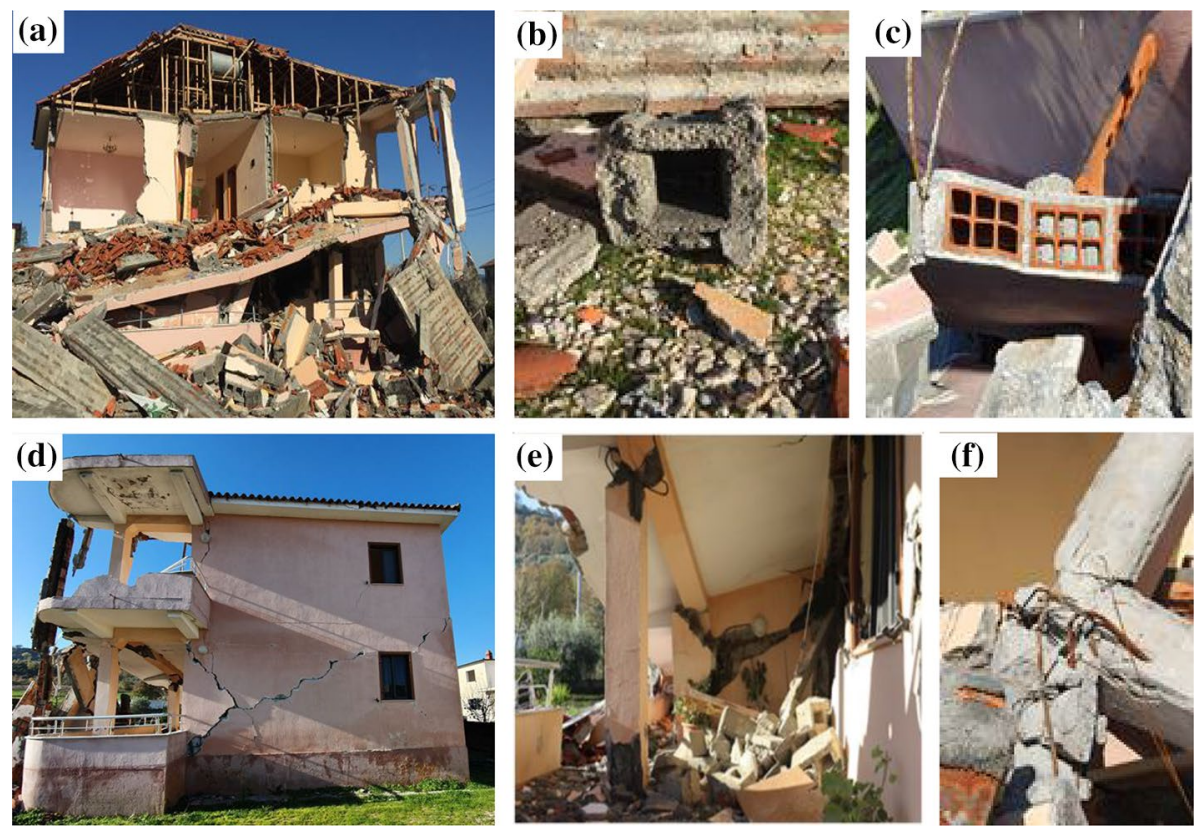

Fig. 9 Single-family rural houses in Bubq. a Failure of the front part of the building due to the collapse of the portico porch, $\mathbf{b}$ hollow concrete blocks of the bearing walls, $\mathbf{c}$ detailing of the hollow core prefabricated concrete slab, d severe crack of the rear building's façade due to the failure of the portico porch, $\mathbf{e}$ internal view of the portico porch, $\mathbf{f}$ details of the joint failure due to poor smooth reinforcements, which are completely corroded 
damage confirms that the failure is triggered by the joint failure of columns in the portico porch, as highlighted by the horizontal cracks on the top end of the 1 st storey columns and overturning of the side façade.

\subsection{Multi-storey RC buildings}

Among the different RC building typologies that can be found in Albania, the mission focused mainly on RC multi-storey buildings. This is justified by the following: (1) relevance, i.e., many multi-storey RC buildings are present in the Albanian territory and in many of the areas significantly affected by the earthquake; (2) such mid-rise structures were consistently damaged while low-rise RC buildings experienced none or very small damage; (3) these buildings have been designed according to the design standards and therefore, the observed damage allows a critical discussion of the code. This is not always the case with other types of low-rise RC structures that were designed outside the code or, in some cases, built by the owner even without a design; (4) these structures are characterised by some 'unexpected' design characteristics which make them different from typical multi-storey buildings located in other seismic areas in Europe.

The Albanian KTP-N.2-89 code has been already illustrated and discussed in Sect. 3, however it is worth highlighting a few aspects that are relevant for RC multi-storey buildings. In particular:

1. The strength requirements of the KTP-N.2-89 are lower than those of the Eurocode 8 . Figure 11a shows a comparison of both the elastic and design spectra defined according to the KTP-N.2-89 and Eurocode 8. The example refers to a structure located in an area with PGA $=0.32 \mathrm{~g}$, soil category Type II, response factor $\psi=0.25$ (corresponding to a behaviour factor $\mathrm{q}=4$ in EC8) and a fundamental period $\mathrm{T}_{1}=1.0 \mathrm{~s}$. The corresponding design spectral acceleration are equal to $\mathrm{S}_{\mathrm{a}}\left(\mathrm{T}_{1}\right)=0.064 \mathrm{~g}$ for the KTP-N.2-89 and $\mathrm{S}_{\mathrm{a}}\left(\mathrm{T}_{1}\right)=0.12 \mathrm{~g}$ for the Eurocode 8;

2. Ductility requirements are included in the Albanian code and, despite less detailed, are similar to those of modern seismic design codes. In fact, the KTP-N.2-89 requires:

(1) regularity checks, e.g., uniform masses and stiffness, symmetry, simplicity, etc.;

(2) ductile member detailing, e.g., min longitudinal reinforcements, maximum stirrups spacing, etc.; (3) implicit capacity design, e.g., strong columns-weak beams;
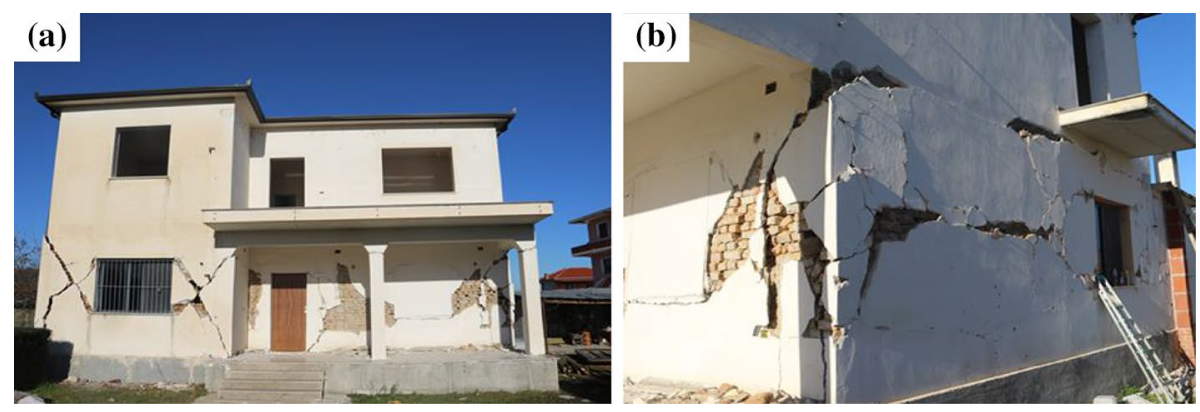

Fig. 10 Single-family rural house in Bubq. a Shear damage highlighted by the presence of diagonal cracks at the first level, $\mathbf{b}$ overturning of the rear facade of the building 

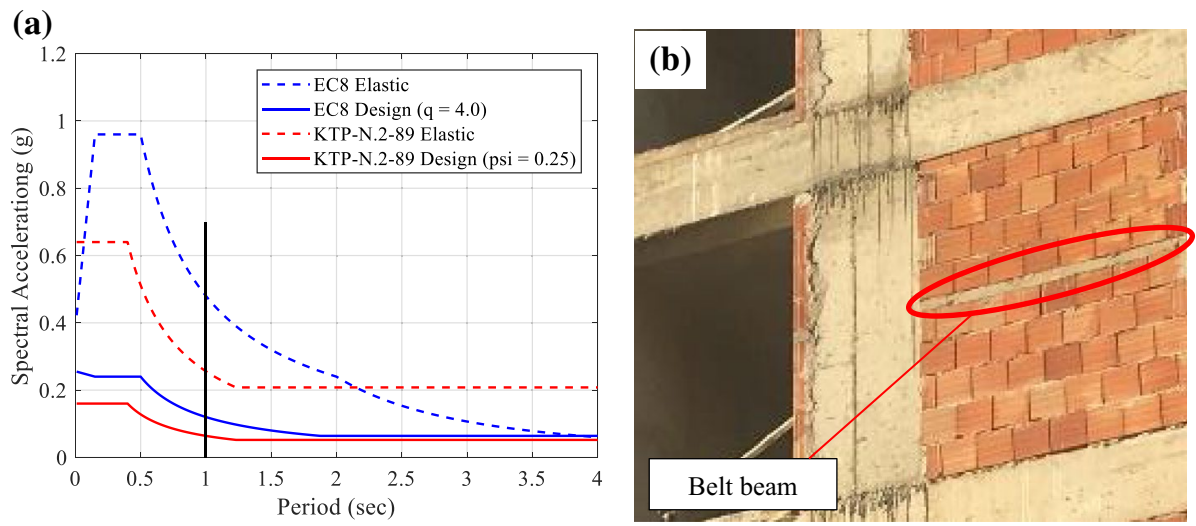

Fig. 11 a Comparison of the elastic and design spectra for one representative site according to the KTPN.2-89 and the Eurocode 8; b belt beam for infill panels in Typical 2010 + multi-storey RC buildings

3. Absence of stiffness requirements i.e., no considerations regarding Damage Limit State (DLS) checks. This aspect could be considered the most evident difference between the KTP-N.2-89 and the Eurocode 8 and is the main one that, in this occasion, affected the seismic response of multi-storey RC buildings. This aspect shows that insufficient consideration is made to the damage of the building under low-intensity (i.e., frequent) earthquakes, which is generally concentrated in the infill panels (for the considered building typology). However, attention is paid to the out-of-plane behaviour of the infills by the introduction of belt beams as shown in Fig. $11 \mathrm{~b}$.

The case study investigated is a typical 2000s multi-storey RC building located in Durrës just across Niko Dovana Stadium. Many buildings with similar characteristics have shown the same damage pattern described here. The structure is characterised by nine storeys with a constant inter-storey height approximately equal to $3.20 \mathrm{~m}$ and by $5 \times 4$ bays with a constant span of $\sim 5 \mathrm{~m}$. The structure is regular in plan and elevation and is illustrated in Fig. 12a. It is worth mentioning that, in this structure, no core wall is included and that the horizontal forces are resisted by the frames only. Based on the several observed buildings of this typology, this has been identified as a common situation where the elevators RC core is absent. The building has shops at the ground level while the upper stories is for residential use.

The structure is characterised by internal and external columns with large dimensions approximately equal to $80 \times 80 \mathrm{~cm}$ and $110 \times 35 \mathrm{~cm}$, respectively. The dimensions of the external column can be observed in Fig. 12b, due to the formation of the vertical cracks in the plaster. Figure 12b shows also the cracks corresponding to the position of the beams which have a depth equal to the thickness of the floor slab (approximately $30 \mathrm{~cm}$ ). This structural configuration of strong columns-weak beams is most probably the outcome of low design accelerations and lack of stiffness requirements.

The infilled panels are made by large hollow bricks $(25 \times 25 \times 20 \mathrm{~cm})$, with horizontal holes as shown in Fig. 12c. The interaction of the flexible structure with the stiff infills led to significant non-structural damage. In fact, infill panels in these structures are often characterised by shear cracks. Moreover, some of the unconfined panels have collapsed (Fig. 12b), or experienced heavy damage. In addition, as shown in Fig. 12d, the damage 

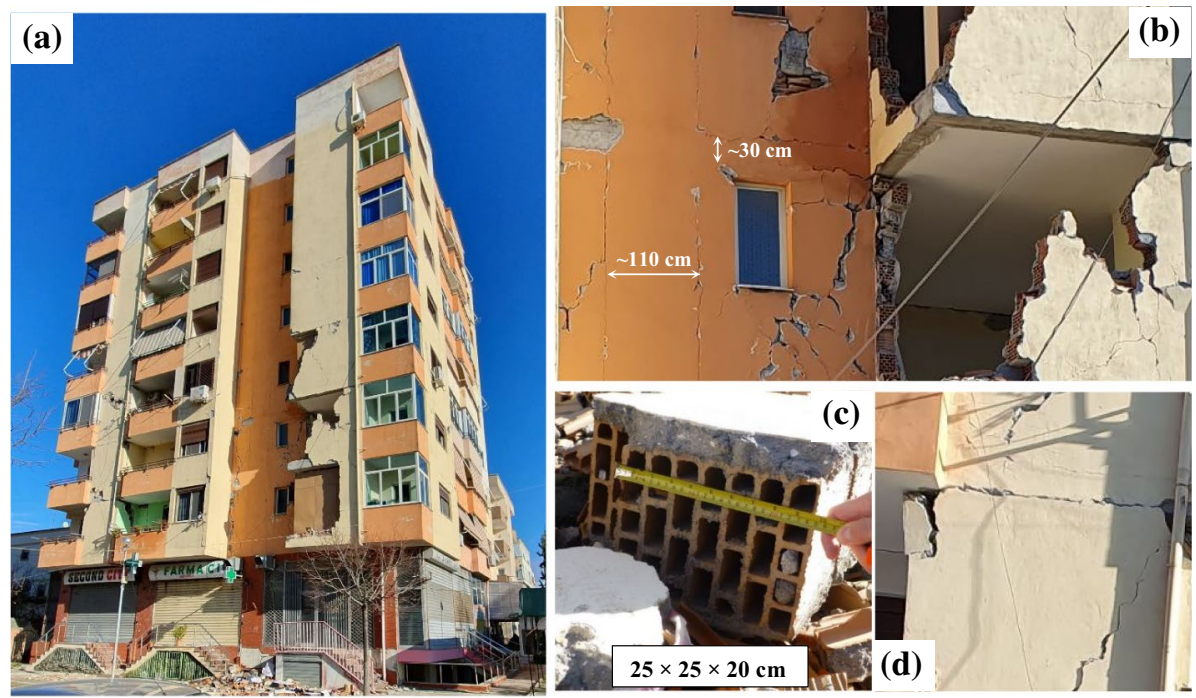

Fig. 12 Typical 2000s multi-storey reinforced concrete (RC) building compliant with KTP-N.2-89. a Building overview and extended damage, $\mathbf{b}$ cracks in the plaster and identification of beams and columns, c dimension of the hollow bricks of the infill panels, $\mathbf{d}$ detachment of the infill panel and formation of horizontal cracks

pattern is also characterised by horizontal cracks at floor level in the lower side of the floor slabs. This is related to the lack of construction detailing and a poor connection between the top side of the infill panels and floor slabs. This configuration promotes the detachment of the infills from the beams and this damage pattern is distributed over the first five storeys of the building. Figure 13 shows a closeup of the damage pattern of the eastern façade of the building which highlights the significant vulnerability of this type of stiff infill panels, especially when unconfined.

It is worth mentioning that, despite the KTP-N.2-89 is currently enforced in Albania, for more recent designs (i.e., after 2010), it became a common practice among design engineers to use recommendations from the Eurocode 8 to overcome the lack of detaining in the recommendations of the Albanian code. For example, although the KTP-N.289 code requires that the columns must be stronger that the adjacent beams, it does not provide a quantitative formulation to perform this hierarchy of strength requirement and in these cases, the detailed formulations provided in Eurocode 8 are usually adopted by practitioners. However, Eurocode 8 is not adopted in its entirety, i.e., recommendations in the Eurocode 8 that are not also present in the KTP-N.2-89 are not applied. For example, it is unlikely that the displacement-based checks for the damage limit state are applied. This insight is based on personal communication with local engineers. In order to investigate this aspect of the design, more recent buildings (i.e., after 2010) designed according to KTP-N.2-89 while including integrations from Eurocode 8 have been also widely investigated.

As per the case study described, also in newer buildings, the infilled panels are generally composed of large hollow bricks $(25 \times 25 \times 20 \mathrm{~cm})$ and are used both for the external and the internal walls. Consistently with the previous case study, significant non-structural damage was observed due to the interaction of the flexible structure with the stiff infills for both unconfined external and internal partitions. Clearly, the lack of 


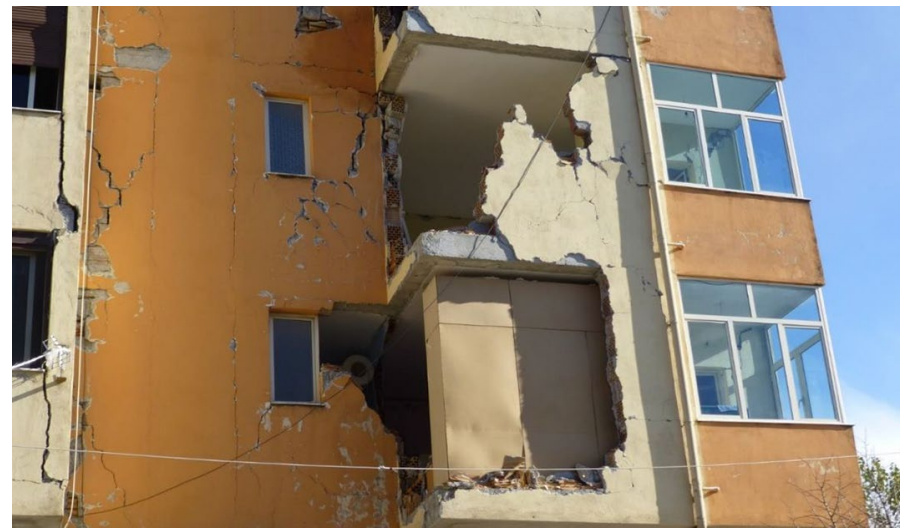

Fig. 13 Typical 2000s multi-storey reinforced concrete (RC) building compliant with KTP-N.2-89. Damage layout in the eastern façade of the building

confinement significantly affected the seismic response of the non-structural components, leading to shear cracks but also to out-of-plane failure of the infills. This is also highlighted in Fig. 14, showing how the belt beams for the infills are ineffective when used in unconfined frames. It is worth mentioning that many buildings with similar characteristics showed the same damage pattern.

The observed damage in these recent 2010 + multi-storey RC buildings, despite less extensive, is very similar to the one described for the 2000s structures. The damage pattern highlights a significant need for additional design requirements to be included within the KTP-N.2-89 such as the inclusion of Damage Limit States checks and the need to avoid unconfined infills. However, it is noteworthy that the Damage Limit States requirements of the Eurocode 8 have demonstrated to be ineffective in a number of occasions e.g., De Luca et al. (2018), thus more strict limits should be used to ensure the design prescribed behaviour of the infills.

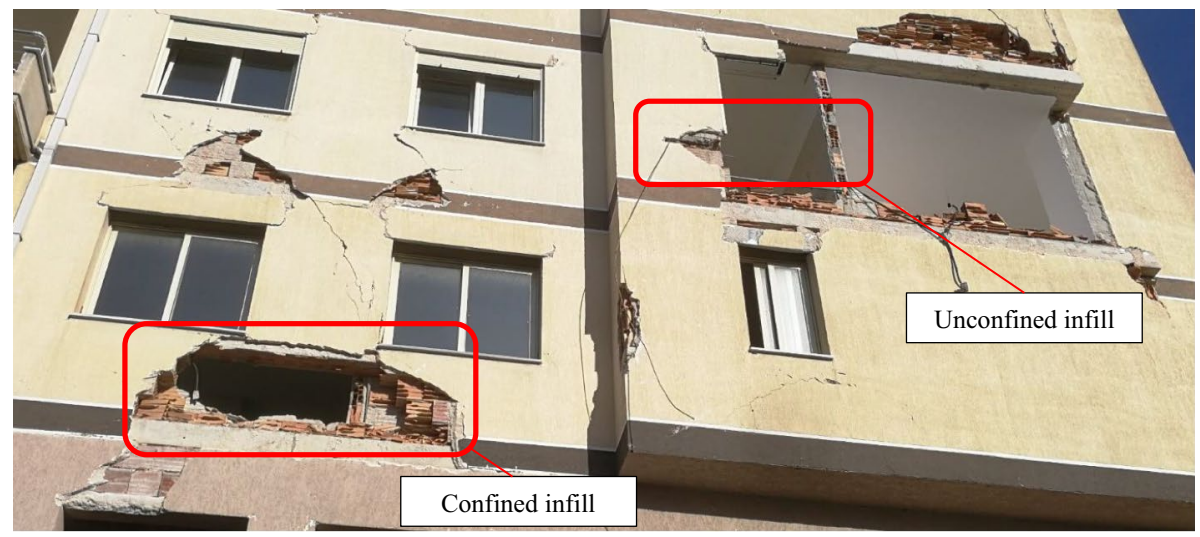

Fig. 14 Typical 2010+multi-storey reinforced concrete (RC) building compliant with KTP-N.2-89 with integration based on the Eurocode 8. Effects of the belt beams in confined and unconfined infills 
Among those investigated, very few RC buildings showed structural damage. It is important to highlight that no reference is herein made to the collapsed buildings. Indeed, such buildings were already demolished at the time of the mission and no considerations are reported here due to lack of direct observations. Figure $15 \mathrm{a}$, b show respectively the shear and axial load failure of one external and one internal columns of a RC multi-storey building in Durrës. Although the year of construction is unknown, it is evident that the quality of both materials and structural details is very poor for this case study. Figure 15 shows the presence of weak concrete (possibly with low percentages of cement), smooth aggregates, smooth longitudinal bars, small stirrups missing the $135^{\circ}$ hook and showing a particularly large spacing. Based on this information, it is fair to say that likely this building was designed and/or constructed without abiding the code and with poor construction materials and execution.

\subsection{Pre-1990 prefabricated large-panel buildings}

As many other countries in Eastern Europe, in the 1960-1970s Albania responded to the growing demand for new houses utilising the emerging trends for industrialization of the construction process and mass construction of prefabricated residential buildings (see Fig. 5d) based on large-panel prefabricated RC elements as illustrated in Fig. 16. These buildings were built according to standardised templates approved by the Albanian governmental authorities and hence, they represent a widespread standardised technology in Albania. During the 1970s large-panel buildings spread throughout the country and become the main type of construction in the Albanian cities such as Shkodër, Tirana, Durrës, Lushnjë, Burrel, Elbasan, Berat, Pogradeci, Laç, Lezhë, Korçë, Tepelenë, Gjirokastër (Abazaj 2019). Most of these buildings have five or six storeys and comprise different modules, the number of which depended on the urban project.

Under earthquake loading the prefabricated wall behaves as one structural unit composed of interacting wall elements as shown in Fig. 16c, d. This structural interaction within the wall needs to be secured by structural connections that resist the required shear, tensile and compressive forces. If the strength of the horizontal and vertical joints exceeds the forces in the interface between the panels, the prefabricated panel wall will
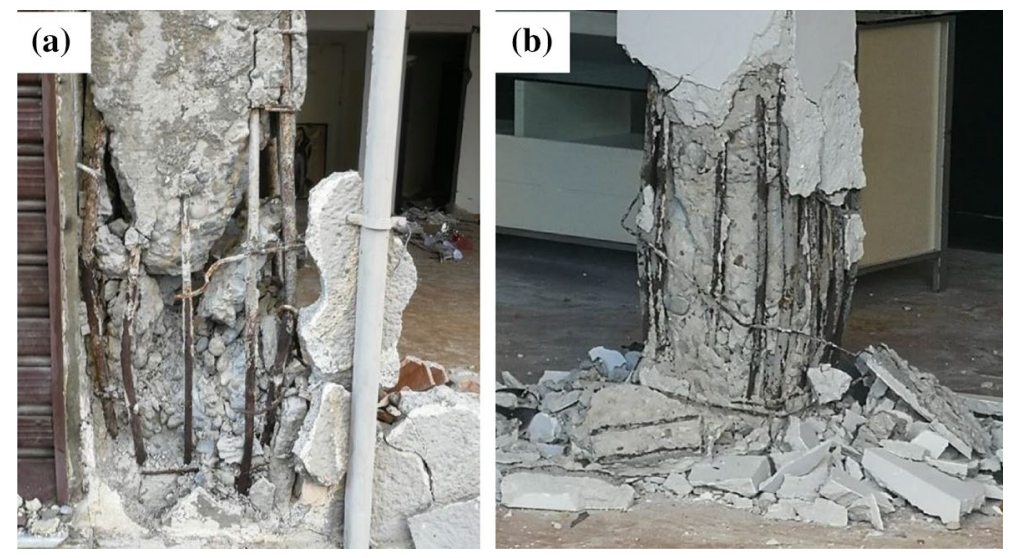

Fig. 15 Case with structural damage showing shear and axial failure in a external column; b internal column 


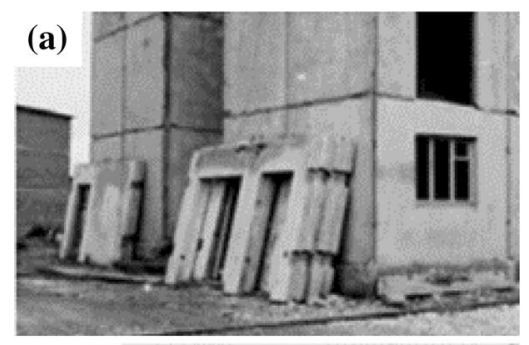

(c)

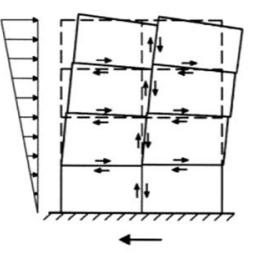

(e)

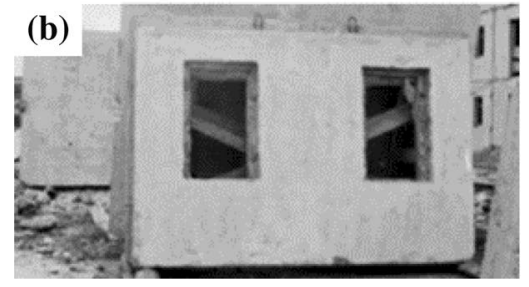

(d)
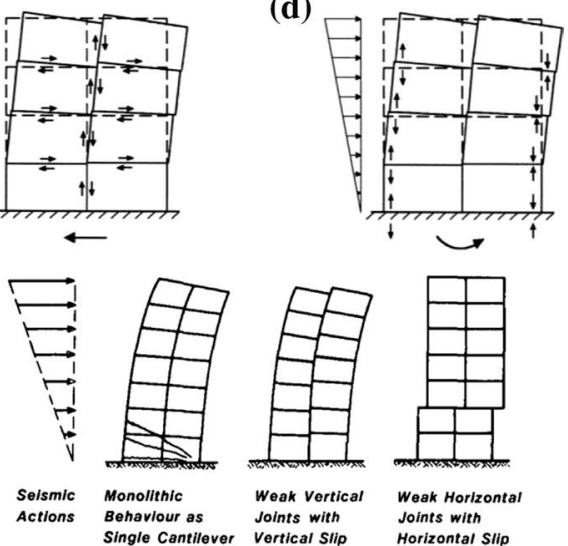

(1)

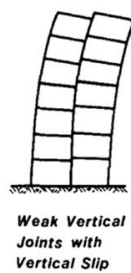

(2)

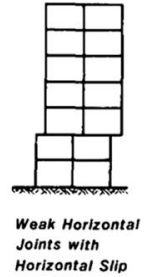

(3)

Fig. 16 a and b Large-panel buildings in Albania; $\mathbf{c}$ in-plane shear forces of prefabricated wall; $\mathbf{d}$ in-plane tensile and compressive forces of prefabricated wall. e Different behaviours and possible failure modalities. Based on Abazaj (2019), fib Bulletin 432008 and UNDP/UNIDO 1985

have monolithic behaviour under lateral load as shown in Fig. 16e, and the structural damage will be concentrated in the form of diagonal cracks in the panels. However, in prefabricated concrete wall systems there may be significant slip (shear displacements) along the vertical and horizontal joints. Figure 16e also shows horizontal actions applied to a large-panel cantilever wall in which slip has occurred along both vertical and horizontal joints due to shear forces transferred along these joints. The effect of slip along the horizontal and vertical joints is to reduce the stiffness of the system. It is difficult to say which will be the prevailing seismic response and failure mode of largepanel walls under earthquake loads. The observations in past earthquakes in Romania, Armenia and Bulgaria suggest that slippage between panels is likely to occur since most of the reported damage was in the form of horizontal and vertical cracks in the interfaces between panels. This situation with 'strong panels-weak joints' is also related to the high-quality control of the prefabricated elements which provides the prefabricated panels with a high concrete resistance. However, the situation with 'strong joints-weak panels' cannot be excluded and should be checked during the assessment procedures. In addition, in the most common situations with 'strong panels-weak joints', the slippage and rocking between panels, is likely to provide a significant friction damping which is beneficial for the seismic performance of these structures and could be one of the reasons for the good seismic performance of large-panel buildings observed in past earthquakes.

The team visited two neighbourhoods with large-panel buildings, in Laç and Durrës. All buildings seemed to have poor maintenance and many signs of deterioration were visible on the facades. However, there were no external signs of earthquake-induced damage in any of the buildings. An inspection from inside showed minor cracking in the interface between the panels in the first two floors-vertical cracks in the contact zone between two wall panels, and horizontal cracks in the contact zone between slab and wall panels. These are typical crack patterns in large-panel buildings in the onset of structural damage when the damage is mainly in the form of cracking of the grouting between the panels and does 
not affect the structural safety. Cracks in the wall panels and damage in the dowels were not observed in any of the inspected large-panel buildings in Laç and Durrës.

\subsection{Pre-1990 masonry buildings}

In Albania, masonry buildings were widely used for residential and public purposes between 1945 and 1990, when the Albanian building design codes underwent several changes, as discussed in Sect. 3. The first masonry buildings were 1 or 2 storeys and constructed using different types of masonry such as stone, and clay bricks. Buildings from 1945 to 1963 were mostly constructed based on experience of engineers and simplified calculations. The first standardised design template was approved by the Albanian governmental authorities in 1949 for a 2-storey adobe building. Successively, a large variety of standardised design templates for buildings of 3 to 5 masonry storeys were implemented between 1963 and 1978. After the 1979 earthquake near Shkodra, many 5-storey masonry buildings were severely damaged and therefore the code was revised with the publication of KTP-N.2-89 which is the current seismic design code in Albania (Bilgin and Hysenlliu 2020). As reported in Sect. 4.1, masonry buildings together with RC buildings are still in use and represent a high percentage in the residential building stock of the country. These buildings can be classified in two different typologies: (1) URM buildings with load bearing walls as shown in Fig. 17a; (2) CM buildings made of load bearing walls confined with RC tie-elements as shown in Fig. 17b.

Typical masonry buildings are built as isolated constructions with regular plan and regular elevations. The majority of these buildings have a rectangular plan or irregular plan geometry with symmetrical distribution of the load bearing walls. Their plan can vary in size, while the floor height is generally $2.8 \mathrm{~m}$. Openings have regular layout and concrete lintels over the openings are commonly used to transfer gravitational loads. The floor systems are either RC slabs or hollow core prefabricated concrete panels. The former is commonly a $150 \mathrm{~mm}$ thick slab, and the latter consists of a $220 \mathrm{~mm}$ thick slab on top of prestressed RC joints. The wall thickness is $380 \mathrm{~mm}$ in the first two storeys and $250 \mathrm{~mm}$ for the remaining ones, while partition walls have thickness of $120 \mathrm{~mm}$. These are made of solid fired clay bricks with dimensions $250 \times 125 \times 60 \mathrm{~mm}$ or silicate bricks with dimensions $250 \times 125 \times 65 \mathrm{~mm}$. Bricks are bonded using cement or silicate mortar. The typical masonry types observed on site are reported in Fig. 18a-c. Tie-elements in
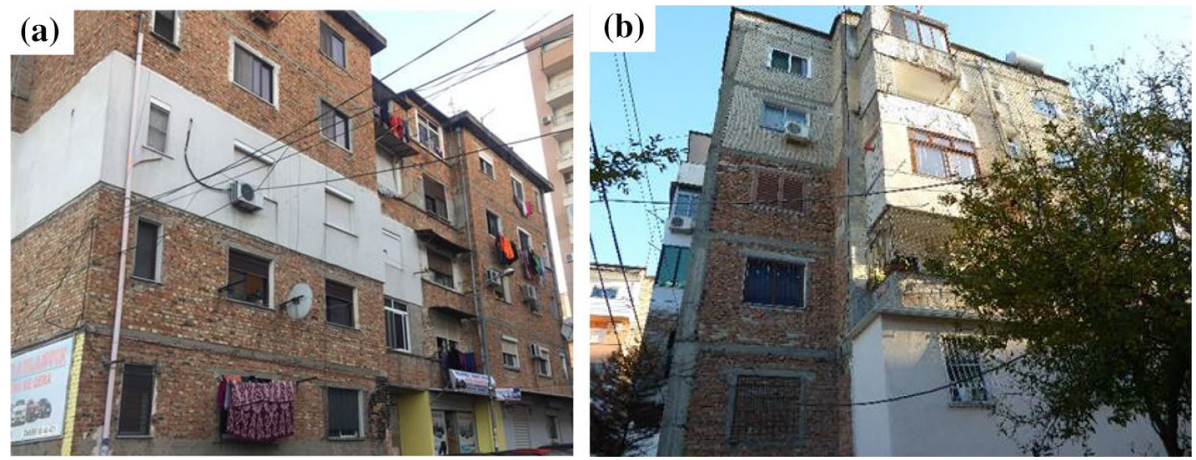

Fig. 17 Typical 5-storey a unreinforced masonry (URM); b concrete-masonry (CM) buildings in Durrës 
the CM buildings (see Fig. 18d, e) consist of RC columns with typical cross section of $380 \times 380 \mathrm{~mm}$ and RC beams with depth of $250 \mathrm{~mm}$ or $380 \mathrm{~mm}$, depending on the wall thickness at their locations. The concrete class is typically $\mathrm{C} 16$, or lower, while the typical steel grade is S220 (Bilgin and Korini 2012).

During the survey it was observed that both URM and CM buildings made of fired clay bricks and RC slabs showed a good seismic performance. Severe damage was not observed, and buildings were not tagged as (red) unsafe in these cases. Amongst others, the good interlocking of the bearing walls in URM buildings was highlighted by the absence of cracks along the façade edges, which is typical of masonry buildings with poor connections among adjacent walls. In addition, the good seismic response is also associated to the typical box behaviour which occur thanks to the good connection and stiffness of the RC slabs distributing the lateral loads on the resisting walls. In the CM buildings, a RC system embraces the masonry walls with frame elements. Their good seismic performance is well known and was observed in various past seismic events (Brzev et al. 2010; Borah et al. 2019). Their capacity is provided by the efficient interactions between the masonry walls and the confining elements given by the shrinkage in the concrete casted after the construction of the walls. These effective connections ensure that CM typologies behave as a whole up structure which is capable to sustain larger deformation and allow high strength and ductility.

The major deficiencies observed for these buildings are related to irregularities in elevations due to unauthorised interventions such as the closure and creation of new openings, use of different masonry for reparation, and introduction of additional floors carried out by the owners of the single dwellings as showed respectively in Fig. 19a-c. These alterations, together with the lack of maintenance, degradation of the mechanical properties of the material, and change of the load paths, can become the origin of damage and deteriorations, which may increase the seismic vulnerability of the structure over its lifetime.

Despite the good performance observed for these buildings made of fired bricks and RC slabs, structural failures were reported for three URM (one 3-storey and two 5-storey) buildings made of solid silicate bricks and hollow core prefabricated concrete slabs, located in Thumanë. The causes of collapse for these buildings are associated with the poor mechanical properties of the silicate bricks and the lack of connections between the
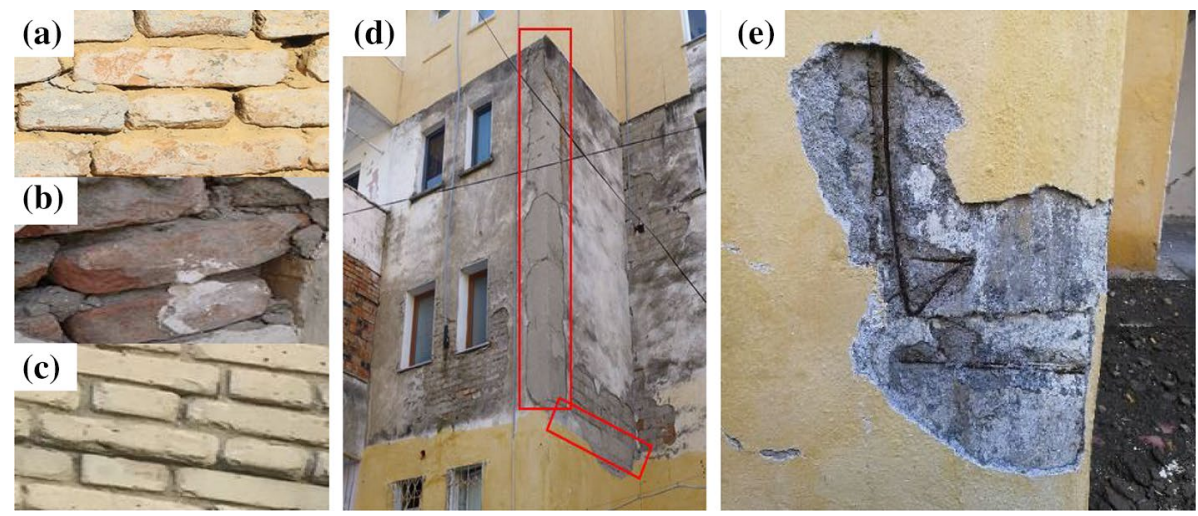

Fig. 18 Typical bricks for load bearing walls. Solid clay bricks with a silicate mortar, b cement mortar, and c silicate bricks with silicate mortar. Details of concrete-masonry (CM) buildings, d reinforced concrete columns and beams, e reinforcements 

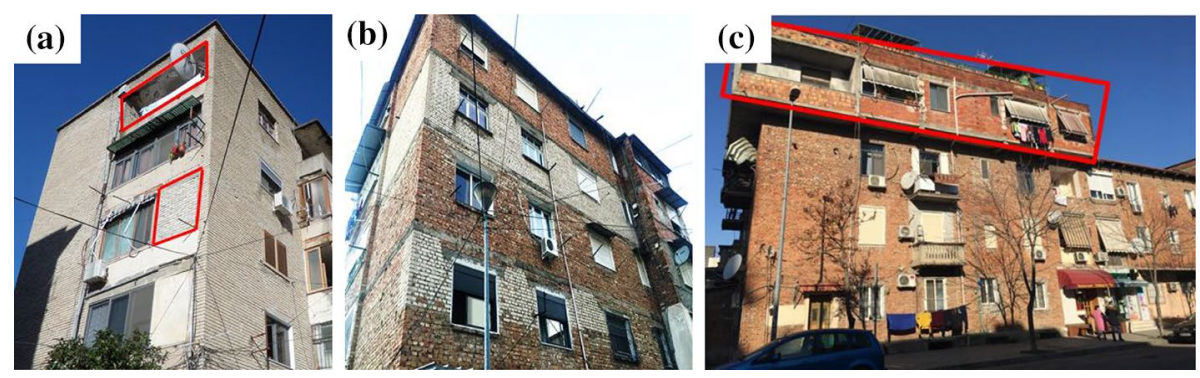

Fig. 19 Unauthorised interventions on unreinforced masonry (URM) buildings in Durrës. a Irregularities in the opening layout due the closure of part of the balcony; $\mathbf{b}$ use of different construction materials and $\mathbf{c}$ presence of an additional floor

prefabricated concrete slabs and the bearing walls failing in overturning. Inspections in Thumanë were carried out after the buildings were already demolished, therefore information related to these failures were provided by local engineers.

URM buildings made of silicate bricks with hollow core prefabricated concrete slabs were also inspected in the city of Lezhë, located in the northwest of Albania, about $50 \mathrm{~km}$ from the epicentre. In this area, only a few buildings were (red) tagged as unsafe by local engineers, although the damage consisted of non-structural damage on external bearing walls and light shear diagonal and X-shape cracks on internal bearing walls.

More severe damage was observed on buildings of the same material and floor types which had undergone large interventions carried out with an inadequate seismic design. Figure 20 reports the damage due to the extension of a 5-storey URM building built in 1974 (green plan in Fig. 20a) with a 4-storey RC building built in 1980 (red plan in Fig. 20a). The different stiffness the URM and RC buildings caused severe pounding damage visible on the external bearing walls (Fig. 20b), the cracks along the opened gap between buildings observed during the internal inspection (Fig. 20c), and the detachment of the staircase due to torsion (Fig. 20d).

A similar seismic performance was also noted for a few CM buildings with silicate bricks and with hollow core prefabricated concrete slabs inspected in Laç (see Fig. 1).
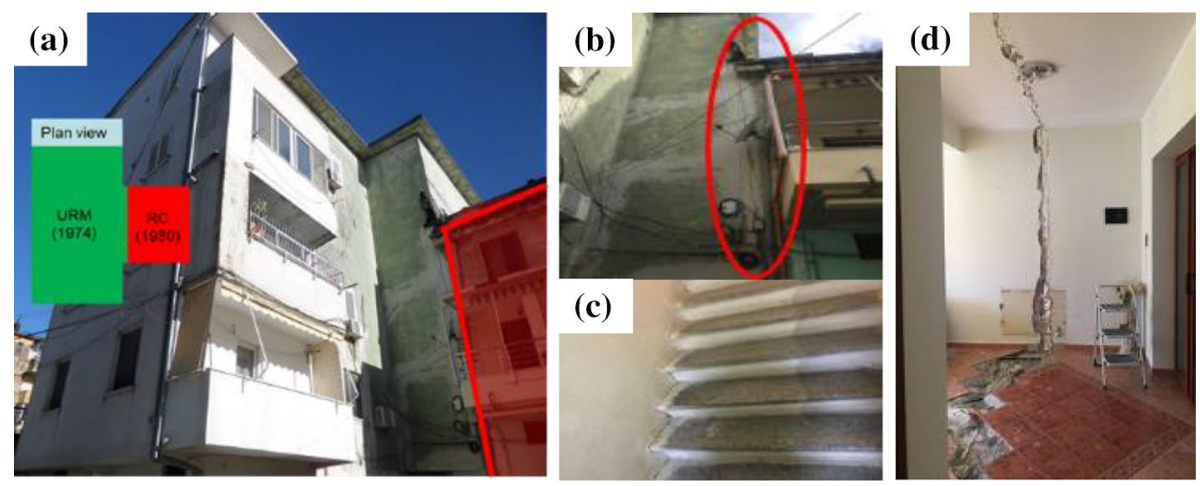

Fig. 20 a 5-storey pre-1990 unreinforced masonry (URM) buildings made of silicate bricks and hollow core precast concrete slabs, inspected in Lezhë, b pounding damage between the URM building and reinforced concrete (RC) building, $\mathbf{c}$ detachment of the staircase, and $\mathbf{d}$ gap opening 
The inspection revealed that these buildings (red) tagged as unsafe by local engineers, were already extremely deteriorated before the earthquake due to a lack of maintenance, highlighted by the presence of corroded and exposed reinforcements, crushed brick units and loss of painting. Furthermore, as these buildings had undergone several structural modifications carried out over time, it is likely that their severe damage is the result of a load path alteration due to construction of additional floors, creation of large openings at the ground level. Typical damage observed for these building, such as the displacement of the prefabricated panels of the prefabricated concrete slabs, yielding of the corrected reinforcements and shear failures in the load bearing walls, are shown in Fig. 21.

\subsection{Historical buildings}

Albania has a rich history and a large presence of built heritage around the country. During the field mission, the castles of Krujë, Prezë and Durrës were inspected to investigate the seismic impact of the 26th November 2019 earthquake. Severe damage and partial collapse were observed on these castles and, in the following sections, the vulnerability of their structural components and the causes of the observed damage patterns are identified through the evaluation of their structural conditions before and after the earthquake.
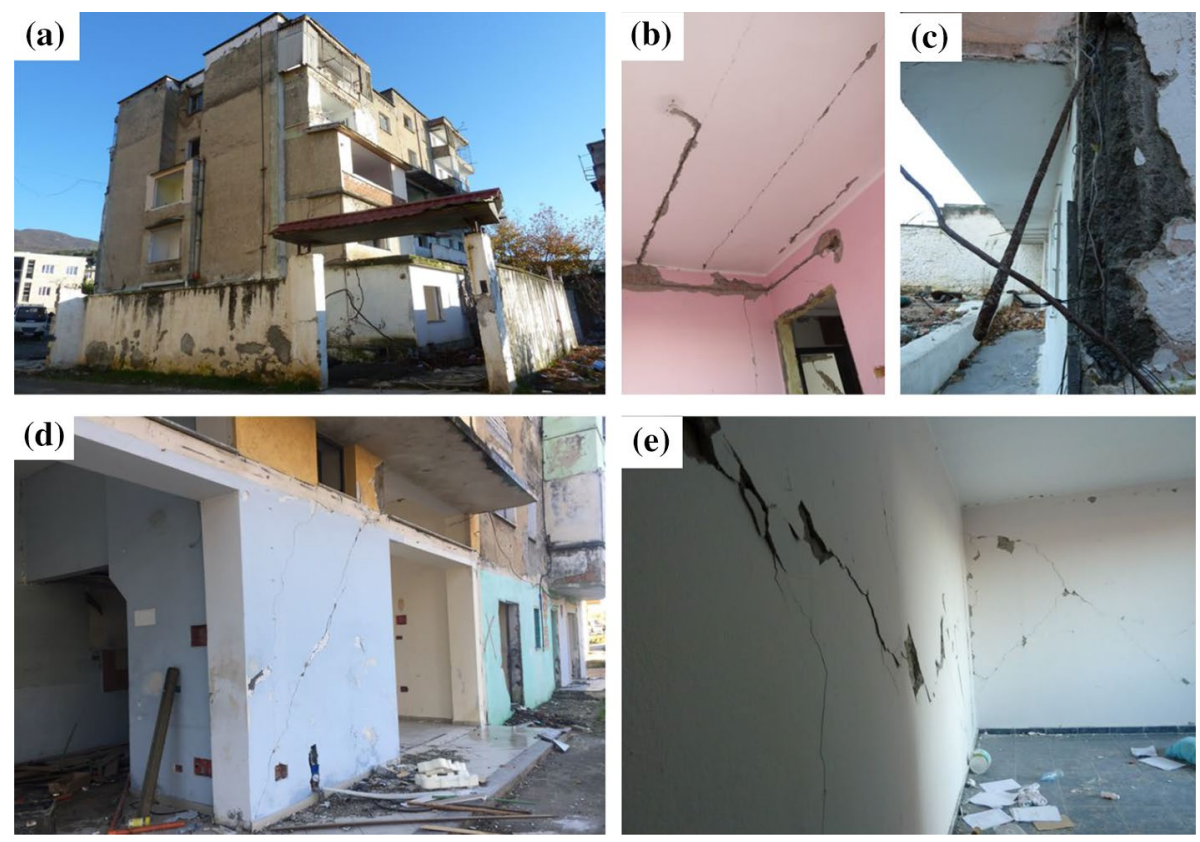

Fig. 21 a 5-storey pre-1990 concrete-masonry (CM) building made of silicate bricks and hollow core precast concrete slabs, inspected in Laç, b horizontal cracks due to the displacements of the prefabricated panels of the precast concrete slabs c yielding of corroded and exposed reinforcements in the column, $\mathbf{d}$ large openings at the ground level failing for shear highlighted by the presence of diagonal cracks, $\mathbf{e}$ internal load bearing walls failing for shear highlighted by the presence of diagonal cracks 

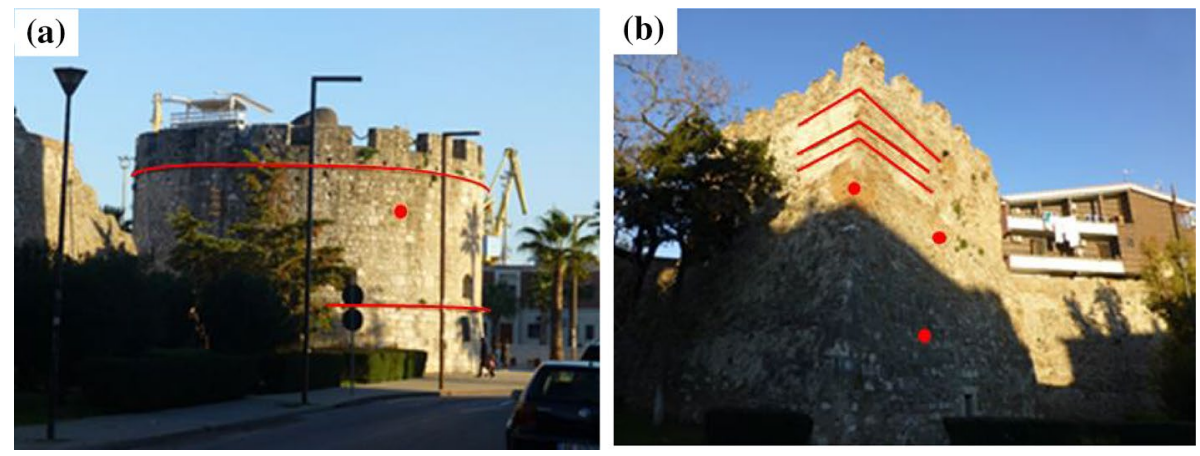

Fig. 22 Visible repairs of the towers of Durrës: a Venetian tower; $\mathbf{b}$ gate tower

(a)

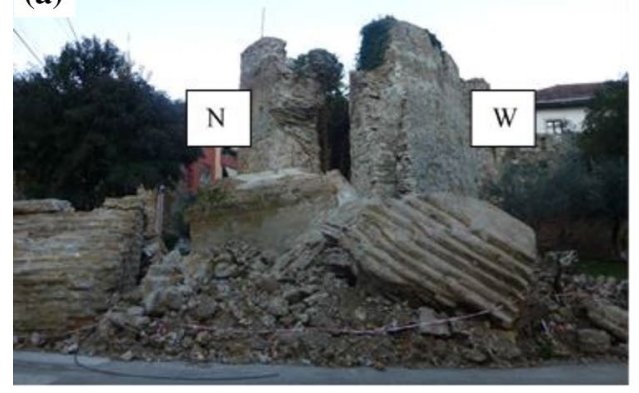

(b)

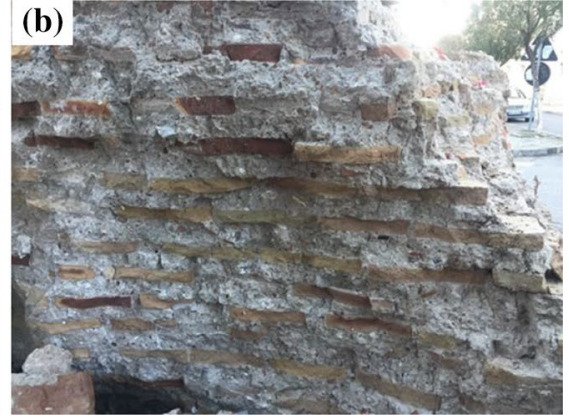

Fig. 23 a View of the gate tower after the November earthquake; $\mathbf{b}$ close view of the collapsed masonry in Durrës

\subsubsection{Durrës Castle}

The Castle of Durrës was built in the first century BCE and acquired its final form in the fifth century with the Byzantine emperor Anastasius I Dicorus. The fortification walls were devastated in an earthquake in 1273 and had to be extensively repaired (https://en.wikip edia.org/wiki/Durr\%C3\%ABs_Castle). Under the Republic of Venice, the castle was reinforced with several guard towers and the walls were reinforced during the Ottoman Empire. Signs of local reconstruction of the masonry walls and repair of the corners with visible metallic elements on the exterior sides are visible on the towers of Durrës in Fig. 22.

In Fig. 23a, the view of the tower after the earthquake shows its seismic response. Based on observation, it is possible to identify that the different masonry types adopted for the wall repair are possibly associated to several interventions performed over time. The North façade $(\mathrm{N})$ shows a stone masonry base course supporting brick masonry walls, changing from brick to stone masonry towards the top. On the contrary, the West façade (W) appears to be made of quite uniform stone masonry until the merlon, which shows a different type of stone masonry. Local repair of stones with bricks is also visible on the wall. The stone masonry at the merlons appears to be in poor condition, with evident decay and loss of mortar. The failure on the $\mathrm{N}$ façade is showing that the walls made of different types of masonry in the corner rely on a poor interlocking, as confirmed by the vertical and regular cracks on the wall edges pointing out an out-of-plane mechanism. 
Furthermore, it was observed that masonry had failed in blocks, with only a small amount of material resulting disintegrated. This is due to the presence of an external layer added to the existing masonry walls without transversal connectors, strengthening techniques practiced during the Ottoman period (Nicolle 2010). This failure type of masonry walls collapsing in blocks is not common in masonry constructions and can be explained by the presence of mortar joints which are thicker than the single masonry brick units (see Fig. 23b). It is unknown whether the brick masonry is part of the original wall or it is a more recent alteration. However, this type of construction with thick mortar joints is quite common in the Byzantine brick masonries, in construction located in seismic areas and/or on subsidizing soils (Binda et al. 1999). Although it was not possible to access to the interior of the tower, it was possible to observe an extensive presence of vegetation growing on the interior side of the walls. The presence of vegetation is sign of both lack of roofing and lack of maintenance, which could be triggers for developing weakness in the masonry walls leading to the observed failure.

\subsubsection{Krujë Castle}

The Castle of Krujë is located on a hilltop overlooking Krujë town and is the symbol of Skanderbeg's rebellion against the Ottoman Empire and considered the most significant expressions of medieval constructions in Albania. The castle is surrounded by fortification walls and sits on a rocky substructure formed by different blocks of rocks fallen off the mountain that constitute the base of the castle. The concerns related to the geological stability of the rocky hill (IRPP/SAAH 2006) led to the installation of anchors (their locations is pointed out in Fig. 24a) used to reinforce the hill's side near the clock tower.

The clock tower is an unreinforced stone masonry structure dating from the twelfth century, with a quasi-pyramidal shape at the bottom and a squared geometry at the top. Access to the tower is understood to be on the front and rear sides from two doors located at different levels, connected through a timber staircase allowing the entry to the top floor. The clock tower underwent a series of interventions: the first intervention took place in the 1920-1930s and consisted on the reconstruction of the masonry of the tower in its middle part; a second intervention took place in the 1970s to reconstruct the top of the tower and included the introduction of a RC rigid floor, possibly with concrete ring beams, and columns with tuff cladding supporting the timber roof. The November earthquake caused the

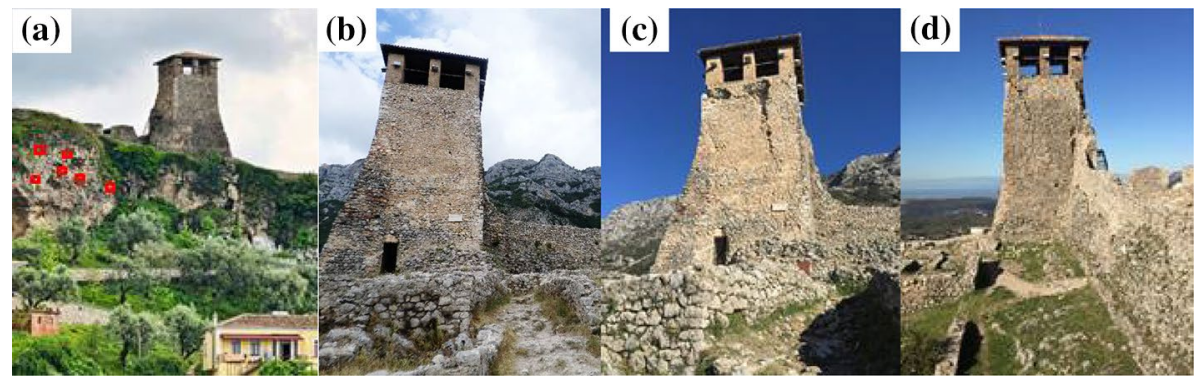

Fig. 24 Krujë clock tower. a The locations of the anchors on the hill's side near the clock tower are highlighted in red (https:/goaslocal.com/tour-category/culture-heritage-tours), b Front view before the earthquake (https://commons.wikimedia.org/wiki/File:Krujë_Watchtower_and_Castle_Walls.jpg), c front view, and $\mathbf{d}$ rear view after the November earthquake in 2019 
formation of some new cracks in the ground around the clock tower. Figure $24 \mathrm{~b}$ shows a view of the tower before the earthquake, while Fig. 24c, d show two different views of after the earthquake. No damage is observed on the belfry, at the top of the tower, which proofs the high rigidity of the RC rigid floor introduced with the 1970s intervention. However, such heavy structural-oriented intervention is considered incompatible with the seismic performance of historic masonry structures (Colapietro et al. 2015), being often source of additional seismic damage. The unsuitability of this intervention of consolidation is confirmed by the global failure mechanism of the tower, highlighted by the presence of the vertical cracks showing an out of plane displacement of a portion of the front and rear tower walls.

On the other side of the castle, another building was found in extremely poor condition at the time of the survey. This is the Tekke of Dollma, shown in Fig. 25, which is a religious construction dated back to 1789 and proclaimed Monument of Culture in 1973 (IRPP/SAAH 2006). The building's square shape turns into hexagonal in the upper part to envelope the central dome. The dome is sitting on squinches which are in turn resting on the stone masonry walls. Figure $25 \mathrm{a}-\mathrm{c}$ show the front and rear view before the earthquake, while Fig. 25d, e show the situation after the November earthquake.
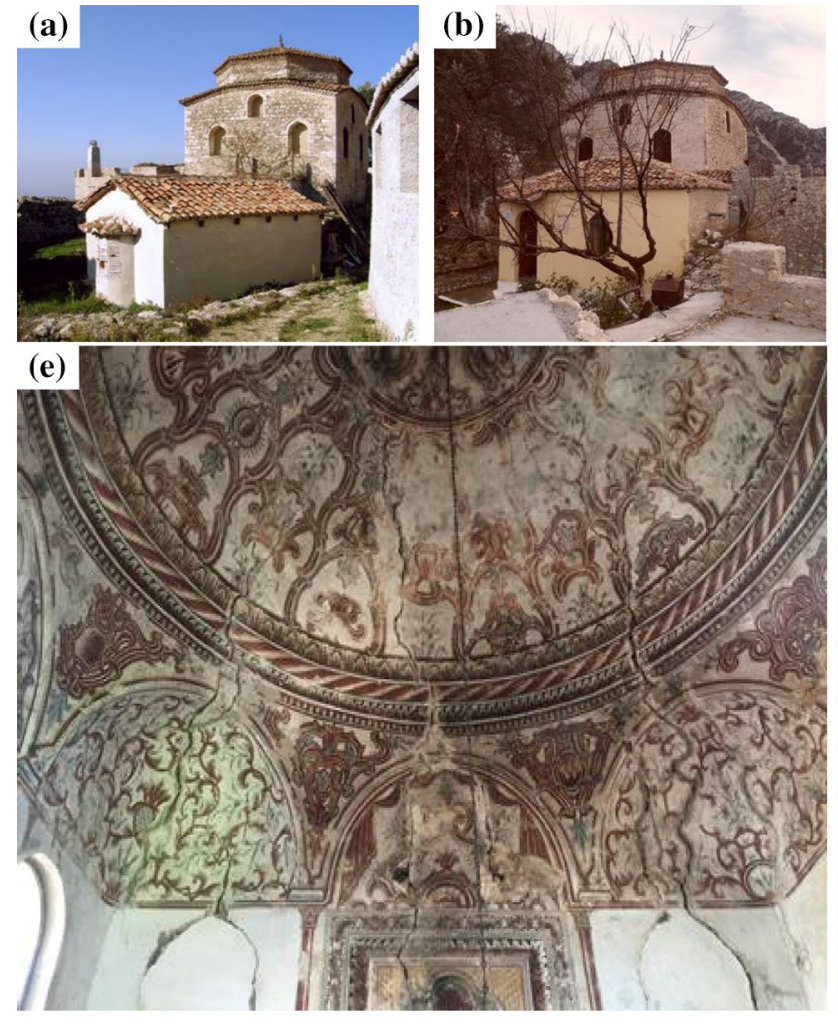
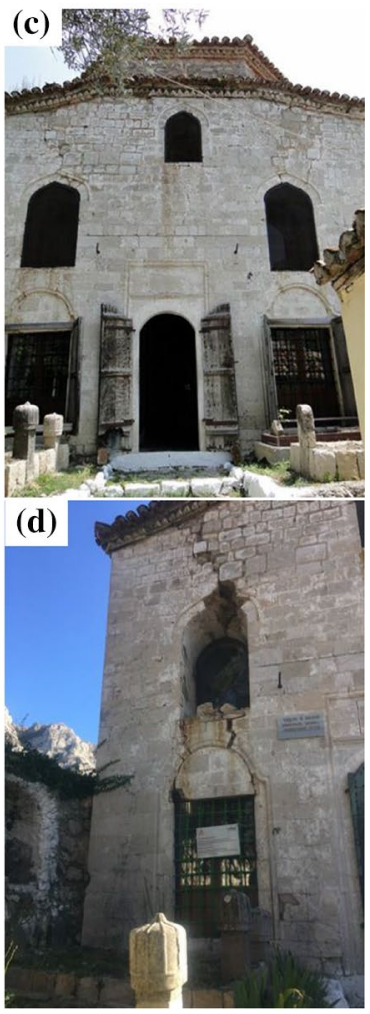

Fig. 25 Tekke of Dollma. a Front view (https://en.wikipedia.org/wiki/Dollma_Tekke), b rear view (https ://mapio.net/pic/p-63037109), c view of the front view before the November earthquake 2019 (http://www. visionsoftravel.org/Krujë-dollma-teqe-albania/), d close view of the extended crack due the November earthquake 2019 and $\mathbf{e}$ internal view of the cracking observed in Tekke of Dollma dome 
When comparing its view before and after the earthquake in Fig. 25c, d, it is possible to observe that in-plane diagonal cracks on the spandrels of the openings of the masonry wall were present at the same locations before the November earthquake. The original causes of the cracking could be associated to the ground instability observed in the area, as well as previous earthquakes (IRPP/SAAH 2006). Therefore, the November earthquake appears to have caused a progression of the existing damage, significantly increasing the size of the pre-existing crack pattern. The failure of the corners is likely to be the cause of the cracking observed on the dome, visible from Fig. 25e. From a glimpse of the inside, the dome presents cracks along the radial arches, with no cracking shown at the crown and regular cracking like 'slices' in the lower part. This type of failure due to excessive lateral loads is caused by movements in the supports of the dome and increase of the span which develop the vertical cracks observed in Fig. 25e (Heyman 2014).

\subsubsection{Prezë Castle}

The Prezë Castle, built in the fifteenth century, was designed to follow the conformation of the hilltop, resulting in an irregular pentagonal shape, with towers in each corner connected with fortification walls. All towers have a circular shape except for one that was reshaped into a $14.5 \mathrm{~m}$ high clock tower in 1852 . The clock tower has a rectangular shape of $4.2 \times 4.2 \mathrm{~m}$ and has two storeys accessible through an internal staircase. The tower has lost its original Ottoman style, which is visible from the photos in Fig. 26a, b capturing the damage suffered by the towers in different periods, most likely due to earthquakes.

Information on the condition of the tower before the earthquake is provided by Mustafaraj and Yardim (2014), who conducted a structural assessment of the tower in 2014. The results of the assessment identified the need of an intervention of retrofitting as the masonry of the tower was found with surface degradation and structural cracks propagating throughout the entire height of the tower, with the most significant cracks observed on the east side. Over the summer in 2019, works have been undertaken on the tower which included the strengthening of the masonry walls with the introduction of metallic ties to prevent overturning failures and the addition of an internal metallic structure to support a spiral staircase to access the 2 nd floor.

A view of the tower after the earthquake is provided in Fig. 26c, d. It is possible to observe that the clock tower completely lost the roof and the columns framing the top floor. Figure 26e, f show the opposite east side of the tower, where the damage is more extended and includes the loss of the masonry of the upper third of the tower, below the top floor. Where the masonry was reinforced with anchors, the walls resisted the out of plane forces by activating the parallel wall and/or perhaps the internal steel structure and engaging the shear capacity of the transverse walls. In this part, the masonry shows vertical cracks between ties, a few of them could have been present since before the November earthquake.

The North tower in Fig. 27 was also damaged by the November earthquake. This tower has a circular shape and is made of stone masonry walls. Visible alteration to the original configuration of the tower observed during the visit are the introduction of a RC floor to create a terrace on the roof of the tower (Fig. 27a) and the construction of a building on the side of the fortification walls and adjacent to one of the sides of the tower (Fig. 27b). The damage occurred on the outer side of the tower, facing the cliff. This side is the most vulnerable due to the lack of confinement provided by adjacent structures. In this part, the masonry collapsed for out of plane mechanism, whereas the stiff slab remained undamaged 

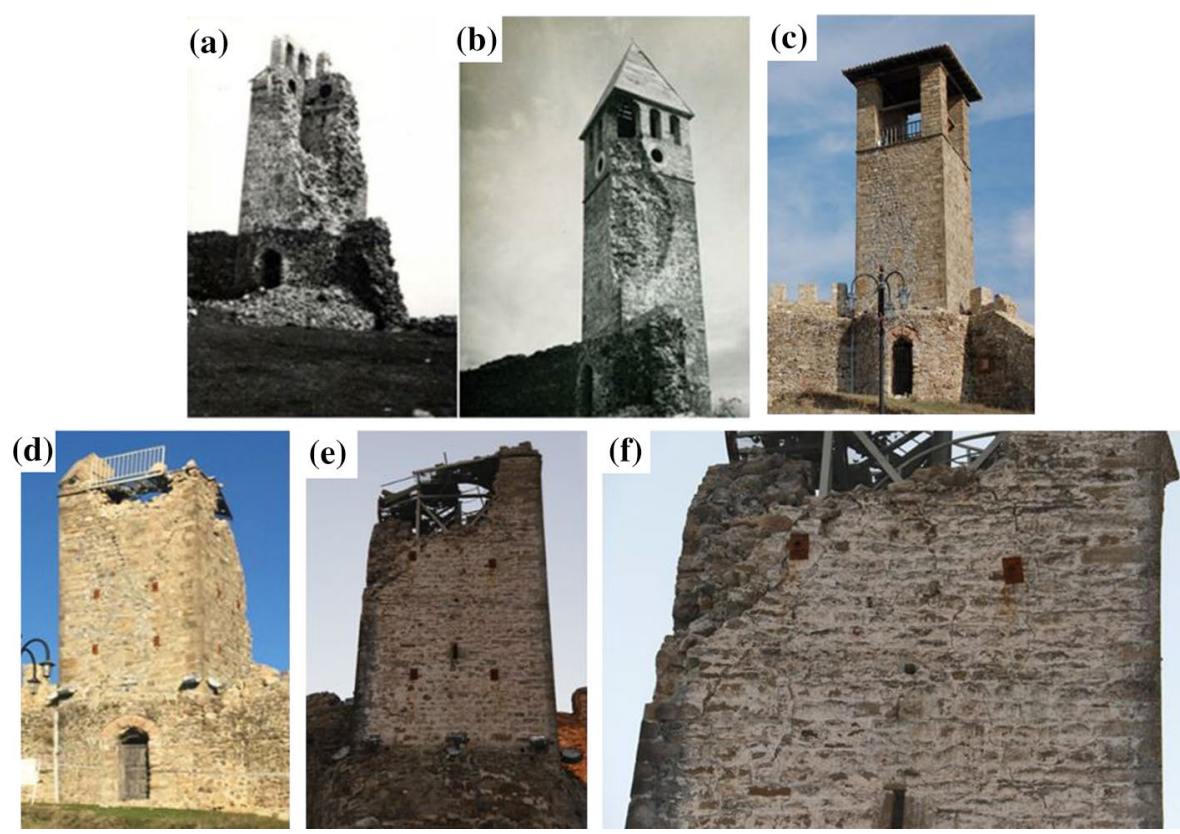

Fig. 26 Prezë clock tower $\mathbf{a}$ and b damage suffered in past earthquakes (Mustafaraj and Yardim 2014). Front side $\mathbf{c}$ before and $\mathbf{d}$ after the 2019 November earthquake. e South side and $\mathbf{f}$ close up of the south side after the 2019 November earthquake
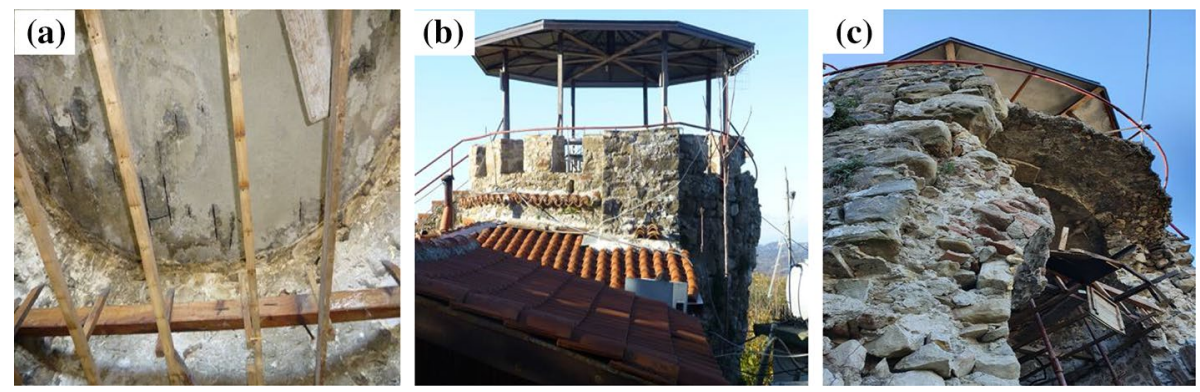

Fig. 27 View of the Prezë north tower and alteriation to the original configuration: a new reinforced concrete (RC) slab, b new construction adjacent to the side of the tower and $\mathbf{c}$ view of the damage to the Prezë clock tower

(Fig. 27c). The presence of the new heavy RC floor activated a larger seismic mass and therefore resulted in a higher demand for overturning capacity on the wall.

\section{Conclusions}

The $M_{w} 6.4$ November earthquake was the strongest seismic events to hit Albania in more than 40 years, and the deadliest earthquake globally for the entire 2019. The fatalities occurred primarily due to the collapse of nine buildings in the city of Durrës and 
in the town of Thumanë (in the Krujë municipality). The Earthquake Engineering Field Investigation Team (EEFIT) team visited the areas mostly affected by the earthquake, focusing on the housing sector. The paper presents an overview of the seismological aspects of the earthquake together with a brief overview of the damage, official loss statistics and the estimated macro- and socio-economic consequences of the event. In addition, it provides a summary of the observed damage to both modern and historical buildings. The key findings regarding the observed seismic performance of the building typologies representative of the Albanian stock are summarised below:

- Single-family rural houses. Despite no casualties were registered due to the failure of these buildings with mixed structural systems, in many of the investigated cases such a typology showed a poor seismic response. This was mainly caused by deficiencies due to inadequate seismic design, irregularities triggered by unauthorised interventions, poor reinforcement detailing, poor material quality, and poor construction quality (due to the challenging economic conditions and the ineffective law enforcement during the construction process in the first years after the fall of the communist regime). There is an urgent need for Albania to join a country-wide programme for seismic assessment of existing buildings within this typology which are potentially bearing significant seismic risk.

- Multi-storey RC buildings. Most of the inspected buildings sustained severe nonstructural damage mainly relating to severe cracking and/or out-of-plane failure of infills in the first 4-5 storeys, cracks in the stair legs and distorted elevator doors. This is due to the combination of flexible structural system and rigid infills, in turn likely due to deficiencies in the current Albanian seismic code, that does not provide drift limitations for Damage Limit States. In addition, the response spectrum definition in the current Albanian seismic code may underestimate spectral accelerations: a comparison shows that in the 1-2 s period range the Eurocode-based spectrum produces almost twice such accelerations. The 26th November earthquake demonstrated that there is a need for a critical review of the current seismic code or for the accelerated adoption of Eurocode, which could help to reduce the seismic risk associated with the future constructions.

- Pre-1990 prefabricated large-panel buildings. Most of the inspected buildings of this category were characterised by poor maintenance and signs of deterioration. However, no external signs of earthquake-induced damage were observed and only minor cracks at the interface between the panels in the first two floors were observed from inside. These are typical crack patterns in this typology which are not likely to affect the structural safety.

- Pre-1990 masonry buildings. Given the height of these buildings, as well as the characteristics of the recorded strong motions, an overall good seismic performance was observed for URM and CM buildings in clay or silicate bricks with RC slabs due to their ability of working as whole up structure under seismic loads, given by the presence of strong connections between walls and rigidity of the horizontal diaphragms. However, many of such typologies built using slabs of prefabricated RC panels (instead of RC slabs) showed severe damage or complete failures due to a lack of connection between the prefabricated RC panels and the masonry walls with a propensity to out of plane failures. This earthquake has shown that a proper seismic risk mitigation program in Albania is needed to address the vulnerability of these buildings. Their standardised design could facilitate the assessment and development of standardised seismic retrofit interventions leading to potential economic savings. 
- Historical buildings. It was observed that the status of conservation of the historical structures was altered by the presence of inadequate structural retrofitting interventions which, together with the presence of pre-existing damage, was found to be one of the main causes leading to the observed failures and severe damage. Therefore, the observed high vulnerability to earthquakes poses a risk to their legacy. The large presence of built heritage and rich history in Albania requires to be preserved for protecting the social-historic values and promoting the economic development of the country.

The 26th November earthquake highlighted the deadly connection between the ineffective law enforcement in the construction process and the high seismic vulnerability due to the presence of unauthorised structural interventions (e.g., the construction of additional floors or column removal on the ground floor). It should be noted that three of the collapsed buildings were 5 to 8 storey high hotels and these collapses could have led to a death toll of hundreds of people if the earthquake had happened during the peak touristic season.

Acknowledgements The EEFIT Albania mission team would like to express sincere gratitude to all the individuals and organisations that supported this activity prior, during and following the mission, without whom would not be possible to carry out the research effectively. This study has received funding from several partners and funding agencies: Fabio Freddi and Roberto Gentile received funding from the EPSRC Grant EP/P025951/1; Roberto Gentile received funding from the Marie Skłodowska-Curie Research Grants Scheme MSCA-IF-2018 (Grant Agreement 843794); Viviana Novelli received funding from the EPSRC Grant EP/P028233/1; Federica Greco received funding from ARUP; Anton Antonov, Stoyan Andreev, Emiljano Zhuleku and partially Enes Veliu received funding from Mott MacDonald.

Open Access This article is licensed under a Creative Commons Attribution 4.0 International License, which permits use, sharing, adaptation, distribution and reproduction in any medium or format, as long as you give appropriate credit to the original author(s) and the source, provide a link to the Creative Commons licence, and indicate if changes were made. The images or other third party material in this article are included in the article's Creative Commons licence, unless indicated otherwise in a credit line to the material. If material is not included in the article's Creative Commons licence and your intended use is not permitted by statutory regulation or exceeds the permitted use, you will need to obtain permission directly from the copyright holder. To view a copy of this licence, visit http://creativecommons.org/licenses/by/4.0/.

\section{References}

Abazaj A (2019) Prefabrication and modular construction dwellings in Albania. Int J Sci Eng Res 10:811-819

Albanian Institute of Statistics (INSTAT) (2001) Population and Housing Census 2001

Albanian Institute of Statistics (INSTAT) (2011) Population and Housing Census 2011

Bilgin H, Hysenlliu M (2020) Comparison of near and far-fault ground motion effects on low and mid-rise masonry buildings. J Build Eng 30:101248. https://doi.org/10.1016/j.jobe.2020.101248

Bilgin H, Korini O (2012) Seismic capacity evaluation of unreinforced masonry residential buildings in Albania. Nat Hazards Earth Syst Sci 12:3753-3764. https://doi.org/10.5194/nhess-12-3753-2012

Binda L, Tedeschi C, Baronio G (1999) Influence of thick mortar joints on the early and late mechanical behaviour of Byzantine constructions. Trans Built Environ 39:1743-3509

Borah B, Singhal V, Kaushik HB (2019) Sustainable housing using confined masonry buildings. SN Appl Sci 1:1-7. https://doi.org/10.1007/s42452-019-1020-4

Brzev S, Astroza M, Ofelia M, Yadlin M (2010) Performance of confined masonry buildings in the February 27, 2010 Chile Earthquake

Colapietro D, Fiore A, De Fino M, et al (2015) Assessment of the seismic vulnerability of a masonry bell tower by non-destructive experimental techniques. In: Psycharis IN, Pantazopoulou SJ, Papadrakakis M (eds) Seismic assessment, behavior and retrofit of heritage buildings and monuments. Springer

De Luca F, Woods GED, Galasso C, D'Ayala D (2018) RC infilled building performance against the evidence of the 2016 EEFIT Central Italy post-earthquake reconnaissance mission: empirical fragilities and comparison with the FAST method. Bull Earthq Eng 16:2943-2969. https://doi.org/10.1007/s10518-017-0289-1 
Duni L, Theodoulidis N (2019) Short Note on the November 26, 2019, Durrës (Albania) M6. 4 Earthquake: Strong Ground Motion with Emphasis in Durrës City. EMSC online report

European Committee for Standardisation (CEN) (2005) EN 1998-1. Eurocode 8: Design of structures for earthquake resistance. Part 1: General rules, Seismic action and rules for buildings. Brussels, Belgium

Grünthal G (1998) European Macroseismic Scale 1998. European Seismological Commission, Subcommission on Engineering Seismology. Working Group Macroseismic scales

Grünthal G, Wahlström R (2012) The European-Mediterranean earthquake catalogue (EMEC) for the last millennium. J Seismol 16:535-570. https://doi.org/10.1007/s10950-012-9302-y

Heyman J (2014) The stone skeleton: structural engineering of masonry architecture. Cambridge University Press, Cambridge

IRPP/SAAH (2006) Integrated Rehabilitation Project Plan. Survey of the Architectural and Archaeological Heritage (IRPP/SAAH). Regional Programme for Cultural and Natural Heritage in South East Europe 2003-2006. Preliminary Technical Assessment (PTA). The castle of Krujë,

KTP-N.2-89 (1989) Technical aseismic regulations. Publication of Academy of Sciences and Ministry of Constructions (in Albanian). Tirana, Albania

KTP 2-78 (1978) Technical design regulations for construction works in seismic regions. Technical Design Regulations, Book I, Publishing House "8 Nëntori”, Ministry of Construction (in Albanian), pp 12-48

Medvedev SW, Sponheuer W, Karnik V (1965) Seismic intensity scale version MSK 1964. In: Working group on seismicity and seismo-tectonics, first meeting, Tbilissi, 8-12 June 1965

Métois M, Benjelloun M, Lasserre C et al (2019) Subsidence associated with oil extraction, measured from time-series analysis of Sentinel-1 data: case study of the Patos-Marinza oil field, Albania. Solid Earth Discuss 11:363-378. https://doi.org/10.5194/se-2019-121

Mustafaraj E, Yardim Y (2014) Structural Assessment of Preza Clock Tower. In: ICESA. Albania

Nicolle D (2010) Ottoman fortifications, vol 95, pp 1300-1710. Osprey Pub

Republic of Albania Council of Ministers (2020) Albania Post-Disaster Needs Assessment Report

Robertson A, Shallo M (2000) Mesozoic-Tertiary tectonic evolution of Albania in its regional Eastern Mediterranean context. Tectonophysics 316:197-254. https://doi.org/10.1016/S0040-1951(99)00262-0

Stein R, Sevilgen V (2020) Albania earthquake strikes highest-hazard zone in the Balkans, devastating nearby towns. Temblor. https://doi.org/https://doi.org/10.32858/temblor.057

The World Bank GPURL D-RAS Team (2019) M6.4 Albania Earthquake Global Rapid Post Disaster Damage Estimation (GRADE) Report

UNDP Albania (2003) Disaster management and emergency preparedness project, Risk assessment of Albania. Tirana, Albania

United Nations Albania (2020) UN support to Albania earthquake recovery

USGS (2020) ANSS Comprehensive Earthquake Catalogue (ComCat). https://earthquake.usgs.gov/data/ comcat/

Publisher's Note Springer Nature remains neutral with regard to jurisdictional claims in published maps and institutional affiliations.

\section{Authors and Affiliations}

\section{Fabio Freddi ${ }^{1}$ D Viviana Novelli ${ }^{2} \cdot$ Roberto Gentile $^{1,3} \cdot$ Enes Veliu $^{4} \cdot$ Stoyan Andreev $^{5}$. Anton Andonov ${ }^{5}$. Federica Greco ${ }^{6}$ Emiljano Zhuleku ${ }^{7}$}

1 Department of Civil, Environmental and Geomatic Engineering, University College London, London, UK

2 School of Engineering, Cardiff University, Cardiff, UK

3 Institute for Risk and Disaster Reduction, University College London, London, UK

4 Scuola Universitaria Superiore IUSS Pavia, Pavia, Italy

5 Mott MacDonald, Sofia, Bulgaria

6 Advance Technology and Research Team, ARUP, London, UK

7 Mott MacDonald, Tirana, Albania 